\title{
The CAPM, National Stock Market Betas, and Macroeconomic Covariates: a Global Analysis
}

Michael Curran

Villanova University, Villanova, PA, USA

Adnan Velic

Technological University Dublin, adnan.velic@tudublin.ie

Follow this and additional works at: https://arrow.tudublin.ie/buschmarart

Part of the Business Commons

\section{Recommended Citation}

Curran, M. \& Velic, A. (2020) The CAPM, National Stock Market Betas, and Macroeconomic Covariates: a Global Analysis, Open Economies Review 31(C)September 2020 DOI:10.1007/s11079-020-09579-2

This Article is brought to you for free and open access by the School of Marketing at ARROW@TU Dublin. It has been accepted for inclusion in Articles by an authorized administrator of ARROW@TU Dublin. For more information, please contact arrow.admin@tudublin.ie, aisling.coyne@tudublin.ie,gerard.connolly@tudublin.ie.

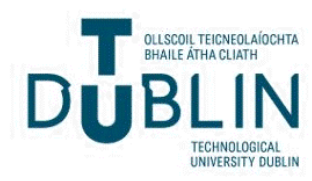




\title{
The CAPM, National Stock Market Betas, and Macroeconomic Covariates: a Global Analysis
}

\section{Michael Curran ${ }^{1} \cdot$ Adnan Velic $^{2}$}

Published online: 12 March 2020

(c) Springer Science+Business Media, LLC, part of Springer Nature 2020

\begin{abstract}
Using global data on aggregate stock markets, this paper finds that the capital asset pricing model fares much better than suggested previously. At shorter time horizons, our results also show that the positive risk-reward relation can collapse during times of high volatility. Compared to other countries, we retrieve evidence of lower systematic risks across frontier equity portfolios. We find that countries characterized by higher levels of openness, exchange rate volatility, and larger economic size are exposed to higher systematic covariances with the world stock market. Conversely, we obtain an inverse link between international reserves and systematic risks in national equity.
\end{abstract}

Keywords Portfolios - Stock market · Cross-country · Systematic risk · Capital asset pricing model $\cdot$ Macroeconomic covariates

JEL Classification F30 $\cdot$ F31 $\cdot$ F41 $\cdot$ G15

We thank John Burger, Charles Calomiris, Scott Dressler, Vahagn Galstyan, Erasmus Kersting, George Tavlas, and two anonymous referees for very helpful comments and suggestions. Ryan Zalla, Bernard Zaritsky, Riley McCarten, Yanyao Shi, Ibrahim Annabi, and Rashaad Robinson provided diligent research assistance.

Electronic supplementary material The online version of this article (https://doi.org/10.1007/s11079-020-09579-2) contains supplementary material, which is available to authorized users.

\footnotetext{
$\triangle$ Adnan Velic

adnan.velic@tudublin.ie

Michael Curran

michael.curran@villanova.edu

1 Villanova University, Villanova, PA, USA

2 Technological University Dublin, Dublin, Ireland
} 


\section{Introduction}

The capital asset pricing model (CAPM) is often presented as one of the cornerstones of financial economics (Lo 2017; Campbell 2018), and highlighted to be of particular relevance to those interested in the long run (Jagannathan and McGrattan 1995). From the pool of asset pricing models in the literature, Berk and van Binsbergen (2016) find that the CAPM is closest to the model that investors use in making capital allocation decisions. Despite providing an intuitive and elegant explanation of asset returns, the theory has enjoyed scant success in empirical assessments (Black et al. 1972; Stambaugh 1982; Campbell and Vuolteenaho 2004; Asness et al. 2013; Fama and French 1992, 1993, 2004, 2006, 2015, 2016; Bai et al. 2019). According to such tests, the popularity of the CAPM is rather puzzling. In contrast, our paper provides more favorable global evidence using national-level data. A further novelty of our work is that we probe into the macroeconomic covariates of systematic risks (betas) in national equity markets.

While most studies focus on the performance of the CAPM intranationally, our paper offers evidence at the international level. ${ }^{1}$ Instead of designating individual firm-level stocks, we concentrate on entire national stock markets across a large sample of developed, emerging and frontier economies, employing them as our micro-level assets. We find overall that the CAPM performs much better than suggested in the literature. Our results indicate that the systematic risks of national stock markets adequately explain corresponding excess portfolio returns in many samples. We in turn find that a number of macroeconomic factors, such as openness and exchange rate stability, play crucial roles in the variation of national stock market betas.

Our paper presents the first truly global study of the CAPM and systematic risk drivers in the context of national stock market portfolios. It comprises over eighty countries and time horizons of up to five decades. By comparison, the cross-country scope of previous work is notably limited (Asness et al. 2013; Frazzini and Pedersen 2014). Much of the literature asserts that the market portfolio of stocks has strong explanatory power for the comovement in stock returns. However, the associated betas, lacking dispersion in many cases, fail to account for the cross-sectional variation in individual expected returns (Fama and MacBeth 1973; Reinganum 1981; Lakonishok and Shapiro 1986; Roll and Ross 1994; Fama and French 1992, 2004, 2015). We aim to rectify this issue by utilizing a large group of more diverse assets in the form of an eclectic mix of national stock market portfolios. Given a global portfolio at the macro level and suitable risk-free rate, the security market line (SML) that emerges from the CAPM in our study ultimately relates country-level stock market

\footnotetext{
${ }^{1}$ Early studies employed short samples with a handful of advanced economies to investigate the investment behavior of citizens of one country when facing an expanded international investment opportunity set or gains from international diversification (Grubel 1968; Lee 1969; Levy and Sarnat 1970; Miller and Whitman 1970; Grubel and Fadner 1971; Solnik 1974, 1977). The subsequent literature diverged by looking at differences in consumption profiles, multifactor models, conditional CAPM, and other variants (Korajczyk and Viallet 1989; Harvey 1991; Dumas and Solnik 1995). Tests were mostly inconclusive.
} 
portfolio returns to country-level stock market systematic risks. ${ }^{2}$ In many instances, our SML regressions reveal an estimated reward per unit of systematic risk that is consistent with the risk premium on the world portfolio, as predicted by the theory. Such congruency between slope estimates and the data is non-existent in past studies.

Scrutinizing the data at shorter time horizons, we retrieve evidence indicating that the usual risk-reward relation can collapse, as suggested by the adaptive markets hypothesis. This typically arises in periods of crisis when significant equity volatility prompts investors to sharply reduce their holdings through a fight-or-flight response. Assessing cross-country discrepancies in betas, we find that frontier markets tend to be characterized by lower levels of systematic risk. According to general performance indicators, frontier markets have also on average performed better than emerging and developed markets, while the relation between alphas and betas in the full panel of countries is flat. ${ }^{3}$

We next turn to identifying the main drivers of national stock market betas. Our results highlight that trade openness, international financial integration, economic size, and exchange rate volatility covary positively with the systematic risks of national stock markets. Conversely, due to their insulation properties, we obtain evidence that international reserves correlate negatively with national equity betas. Notably, our findings imply that deepening international trade ties diminish the incentives of cross-border portfolio diversification.

The remainder of the paper is structured as follows. Section 2 outlines the theoretical framework of our study. Specifically, Section 2.1 lays out the basic capital asset pricing model, while Section 2.2 documents the potential macroeconomic covariates of national stock market betas. In Section 3 we describe the empirical framework adopted, with Section 4 providing data details. Empirical findings are discussed in Section 5. The first subsection on results, Section 5.1, assesses CAPM regression estimates for long and short time horizons. Next, Section 5.2 analyzes if discrepancies in national equity betas are present across developed, emerging and frontier markets. Section 5.3 examines national stock market performance across countries. Finally, Section 5.4 studies the relation between systematic risks in national stock markets and a number of macroeconomic covariates using panel regressions. Section 6 concludes.

\section{Theoretical Framework}

\subsection{Asset Pricing}

In Supplementary Appendix S1, we derive the CAPM equation from a simple oneperiod model of portfolio asset holdings. In our setup, the individual micro-level risky assets $n=\{1,2, \ldots N\}$ are country-level total stock market portfolios, such

\footnotetext{
${ }^{2}$ We confine our analysis to the traditional CAPM alone, as multi-factor models (i.e. augmented CAPMs) are known to diminish the dispersion in market portfolio betas, pushing them toward unity (Ahn et al. 2013; Fama and French 1992, 1996, 2015). Conditional CAPM estimation is also not feasible in our study given our data.

${ }^{3}$ Alpha is the return above that predicted by the CAPM.
} 
as the FTSE 100. Meanwhile, the macro-level market portfolio is the world stock market portfolio, such as the MSCI All Country World Index. This contrasts with the standard approach of employing firm-level stocks and narrower country-level market (benchmark) portfolios. Hence, through the portfolio betas, our approach allows us to identify the systematic risk of each country's overall stock market. Denoting the country-specific aggregate stock market portfolio return by $r_{c}$, and the world market portfolio return by $r_{w}$, the CAPM equation is given as

$$
\mathbb{E}\left[r_{c}\right]-r_{f}=\beta_{c} \underbrace{\left(\mathbb{E}\left[r_{w}\right]-r_{f}\right)}_{\text {SML slope }}
$$

where $\beta_{c}=\frac{\operatorname{cov}\left[r_{c}, r_{w}\right]}{\operatorname{var}\left[r_{w}\right]}$ is the systematic risk of country asset $c$ and $r_{f}$ is the rate of return on a global risk-free asset.

\subsection{Macroeconomic Covariates of Beta}

The macro finance literature suggests a number of potential reasons for comovements between national and world stock markets. Positive correlations may emanate from, for example, global disturbances, such as world interest rate shocks, or common institutional characteristics. Comovements can also arise from the international transmission of country-specific disturbances via cross-border financial asset holdings and trade in goods and services. Specifically, the degree of international trade and financial integration influences the extent to which cross-country business cycles are synchronized, and thus in turn stock market correlations (Frankel and Rose 1998; Kalemli-Ozcan et al. 2001; Bordo and Helbling 2003; Kose et al. 2003; Chinn and Forbes 2004; Imbs 2004, 2006; Calderon et al. 2007; Bruno and Shin 2015; Obstfeld 2015; De Truchis and Keddad 2016). Overall, theory is equivocal about the net effects of cross-border linkages on stock market comovements, with the matter left to empirical assessment. We next discuss in greater detail some of the factors affecting stock market covariances.

\subsubsection{Financial Openness}

From a theoretical perspective, the implications of heightened international financial integration for cross-country business and financial cycle comovements are ambiguous. To illustrate, if the equities of a particular country feature significantly in foreign investor portfolios, then fluctuations in that national stock market will impart wealth effects in the rest of the world. Such domestic developments consequently affect foreign consumer demand, thereby inducing greater cross-border business cycle and stock market synchronization. Financial integration may spur synchronization indirectly by increasing similarities in aggregate output composition (Dées and Zorell 2012). If, for example, FDI flows are deployed to sectors where the source country has a comparative advantage, production structures across participants may become more homogeneous. Conversely, increased financial openness with the rest of the world can also reduce cross-border comovements by enabling consumption 
smoothing through internationally diversified portfolios, without the need for diversified production. Put differently, stronger international financial linkages may imply stronger non-uniform output specialization patterns, and therefore an attenuation of business cycle correlations across countries.

\subsubsection{Trade Openness}

Although it is often associated with enhanced business cycle synchronization, the net effect of higher international trade in goods and services is in fact ambiguous at the theoretical level. From the lens of the demand side, a fraction, that depends partly on trade openness, of aggregate expenditure in a country will be allocated toward imports. An increase in the aggregate demand of the country will therefore raise demand for foreign goods and in turn foreign income levels, thereby engendering output, and thus stock market, comovements across nations.

On the other hand, from the lens of the supply side, the predictions are more mixed. International trade integration may lead to production specialization in countries based on comparative advantage. Hence, in the case of inter-industry trade, comovements across economies weaken. ${ }^{4,5}$ In the context of intra-industry trade, however, trade specialization is suppressed as home and foreign varieties of a particular good are imperfect substitutes. Models of trade within industries typically highlight similar production structures and factor endowments across countries. If intra-industry trade is the dominant form of trade, expansions in some industries will lead to stronger comovements in country output levels. More generally, the net contribution of greater trade openness will depend on the extent to which intra-industry trade dynamics subdue inter-industry trade dynamics.

\subsubsection{Economic Size}

National market size is predicted to covary positively with the degree to which the stocks of a country feature in global investment portfolios (Galstyan and Velic 2018). According to "gravity" models, countries of larger economic size also tend to have stronger economic ties. As a result, higher business cycle and stock market correlations may be more likely amongst such countries. Many supply-side models indicate that equity returns have their roots in the productivity of the underlying real economy, with gains following the path of economic growth. Similar-growth countries can thus observe higher equity market correlations. Under the "financing" hypothesis based on Tobin's q theory for example, countries characterized by larger or more developed financial markets, as proxied by higher market capitalization, can exhibit a more pronounced link between growth and stock returns. On the other hand, technology improvements contributing to rising output levels may not imply higher profits,

\footnotetext{
${ }^{4}$ According to Pentecöte et al. (2015), new trade flows (extensive margin) tend to strengthen specialization and the decoupling of business cycles across countries.

${ }^{5}$ This materializes unless there are significant cross-border (intermediate) input-output linkages running over heterogeneous industries. In this latter scenario, comovements are induced by countries using foreign heterogeneous goods as intermediate inputs in their sector of specialization.
} 
and thus equity gains, if firm competition results in proceeds being distributed to consumers and workers. Finally, in the presence of more domestic multinationals in the country, national stock market performance can rely more heavily on trends in global income and equity growth.

\subsubsection{Exchange Rate Volatility}

Theory offers two different views on the link between exchange rate stability and international correlations of stock markets. The first line of argument is based on the fundamental approach to asset pricing and indicates that a credibly fixed exchange rate, associated with lower volatility, augments cross-country correlations. Under a peg or currency union for example, lower exchange rate volatility implies that cross-border investments carry lower transaction costs. Moreover, fixed regimes can lead to a convergence in inflation and real risk-free rates across relevant countries. Overall, such cross-country symmetry in monetary policies, which may be more likely amongst nations geographically closer to one another, can eliminate disruptive exchange rate shocks to the tradable sector and induce strong business cycle, and in turn stock market, correlations across economies.

Conversely, flexible exchange rates tend to diminish the effects arising from the transmission of country-specific real shocks, thus reducing international comovements. While floating exchange rates are thought to shield domestic interest rates from foreign interest rates (Obstfeld et al. 2004, 2005), it is not entirely clear that this insulation extends to risk appetite and risk premia more broadly (Rey 2013). Noncredible pegs, yielding greater exchange rate volatility, can also induce lower asset return correlations transnationally as regular changes in the likelihood of realignment imply a high variance of interest rate differentials.

The second line of reasoning is based on the contagion explanation of asset price fluctuations (King and Wadhwani 1990). This strand of the literature, in contrast, points to an increase in global correlations when currency markets are more volatile. In particular, contagion effects are highest in volatile markets as a result of herd behavior or noise trading, when significant discrepancies in expectations about fundamentals cause investors to turn to asset prices abroad as an indicator of probable trends in the home market. However, contagion effects are less likely and international correlations fall in the presence of credibly fixed exchange rates that decrease uncertainty about fundamentals. Pegs lacking credibility would culminate in the opposite scenario, with volatility spillovers across economies.

\subsubsection{International Reserves}

Countries holding larger stocks of foreign exchange reserves are more likely to be able to insulate their economies from global shocks, safely riding out periods of international financial stress. As the literature has documented, however, the build-up of reserves may work against the intended purpose of the accumulation by encouraging greater private-sector risk-taking. Such developments could induce volatility and contagion in the region, with enhanced comovements among stock markets. 
Using model simulations, Chutasripanich and Yetman (2015) demonstrate how intervention designed to restrict exchange rate volatility can heighten speculative activity amongst risk-averse speculators, and, hence, may be counterproductive. Caballero and Krishnamurthy (2004) contend that policies of foreign exchange intervention constrain the growth of domestic financial markets and so contribute to the underinsurance of foreign currency risks. Burnside et al. (2004) show how implicit guarantees to foreign creditors of banks can be the underlying cause of self-fulfilling twin banking-currency crises, with banks encouraged to take unhedged foreign currency exposures. Meanwhile, Cook and Yetman (2012) provide empirical evidence that higher foreign exchange reserves offer banks insurance against exchange rate shocks, such that their equity prices become less sensitive to movements in the exchange rate. Lastly, reserve accumulation could depress foreign interest rates, stimulating higher risk-taking abroad too and globally transmitted financial crises (Gerlach-Kristen et al. 2016).

\section{Empirical Framework}

According to the security market line (SML) embodied in the CAPM, discrepancies in average returns in a cross-section of country stock market portfolios will be linearly related to discrepancies in portfolio betas. Our preliminary CAPM analysis in the context of country stock market portfolios entails two phases.

First, employing real returns and assuming that the country portfolio betas, $\beta_{c}$, are constant over the sample period, we estimate the time series regression

$$
\left(r_{c}-r_{f}\right)_{t}=\alpha_{c}+\beta_{c}\left(r_{w}-r_{f}\right)_{t}+\epsilon_{c, t}
$$

for each country portfolio $c$. The equation is also estimated for non-overlapping five-year periods in order to examine changes in systematic risk. We note that working with portfolios, as opposed to individual securities, improves the precision of estimated betas (Blume and Friend 1970, 1973; Fama and French 2004).

Second, using the estimates of $\beta_{c}$ across country portfolios, we estimate the crosssection regression

$$
\bar{r}_{c}=\psi_{0}+\psi_{1} \hat{\beta}_{c}+\varepsilon_{c}
$$

for the entire sample period and the five-year sample periods, where $\bar{r}_{c}$ is the average monthly return for country portfolio $c$. Noting that a bar indicates the monthly average, we expect $\hat{\psi}_{0} \approx \bar{r}_{f}$ and $\hat{\psi}_{1} \approx \bar{r}_{w}-\bar{r}_{f}>0$ (i.e. average risk premium on world portfolio) which is the slope of the security market line. ${ }^{6}$

Concluding our analysis, we examine the potential covariates of systematic risk in national stock markets by estimating the basic reduced-form panel regression

$$
\beta_{c, t}=\alpha_{c}+\delta_{t}+\boldsymbol{\Phi}^{\prime} \mathbf{X}_{c, t}+u_{c, t}
$$

\footnotetext{
${ }^{6}$ Following Fama and MacBeth (1973), we also estimate month-by-month and year-by-year cross-section regressions, obtaining time series means of the intercepts and slopes for testing. This approach yielded similar results. Results are robust to Shanken correction and GMM approach to estimation.
} 
where five-year data are used, $\alpha_{c}$ and $\delta_{t}$ are country and time fixed effects respectively, and $\mathbf{X}$ is a vector of controls in $\log$ form. The inclusion of time dummies allows for the relation between beta and covariate $x_{i}$ for country $c$ at time $t$ to be captured relative to worldwide common patterns in beta and $x_{i}$ at time $t$. Additionally, this core regression is supplemented with pooled panel estimation. While the fixed effects estimator focuses on within-country data variation, the pooled estimator exploits the full cross-sectional variation in the data.

\section{Data}

\subsection{Stock and Bond Market Variables}

We are able to obtain national equity data for 82 countries, comprising 23 developed, 36 emerging and 23 frontier markets. In addition, we gather Morgan Stanley Capital International (MSCI) aggregate indexes covering the three aforementioned groups as well as the euro area. Table 1 provides the list of countries and corresponding stock market indexes (country portfolios) employed. We choose country stock market indexes that represent the largest firms by market capitalization. We use the MSCI All Country World Index (ACWI MXWD) as the global market index (world portfolio). Returns on the aggregate developed, emerging, and frontier stock markets, derived from the MXWO, MXEF, and MXFM indexes respectively, are further considered as overall market (benchmark) portfolio returns within corresponding country subsamples and as secondary proxies of $r_{w}$. "Adjusted" stock market prices are adopted, which are total return indexes that assume dividends are reinvested in the index. ${ }^{7}$ The 10 -year government bond yields of 34 countries are also included in our analysis. The global risk-free rate employed is the 3-month U.S. Treasury Bill return. For the purposes of calculating real returns from the perspective of a U.S. investor, we also retrieve U.S. consumer price index (CPI) and cross-country nominal exchange rate data. All data are collected at the monthly frequency over the period 1968:12017:12. Stock market data are gathered from the Bloomberg repository, while CPI and exchange rate data are retrieved from both Bloomberg and IMF's International Financial Statistics (IFS).

The real return on a given foreign stock market portfolio to a U.S. investor is defined as

$$
\begin{gathered}
R_{p, t+1}=1+r_{p, t+1}=\frac{\frac{S_{t+1}^{*}}{S_{0}^{*}} \frac{E_{t+1}}{E_{0}}}{\frac{P_{t+1}^{U S}}{P_{0}^{U S}}} \frac{\frac{P_{t}^{U S}}{P_{0}^{U S}}}{\frac{S_{t}^{*}}{S_{0}^{*}} \frac{E_{t}}{E_{0}}}=\left(1+r_{p, t+1}^{n o m}\right)\left(1+\frac{\Delta E_{t+1}}{E_{t}}\right)\left(\frac{1}{1+\pi_{t+1}^{U S}}\right) \\
\Rightarrow r_{p, t+1} \approx r_{p, t+1}^{n o m}+\frac{\Delta E_{t+1}}{E_{t}}-\pi_{t+1}^{U S} \approx r_{p, t+1}^{n o m}+\Delta e_{t+1}-\pi_{t+1}^{U S}
\end{gathered}
$$

where $S_{t}^{*}$ is the foreign "adjusted" stock market price index in local currency terms, $E_{t}$ is the nominal exchange rate quoted in U.S. dollar per unit of foreign currency

\footnotetext{
${ }^{7}$ See MSCI methodology for construction details.
} 


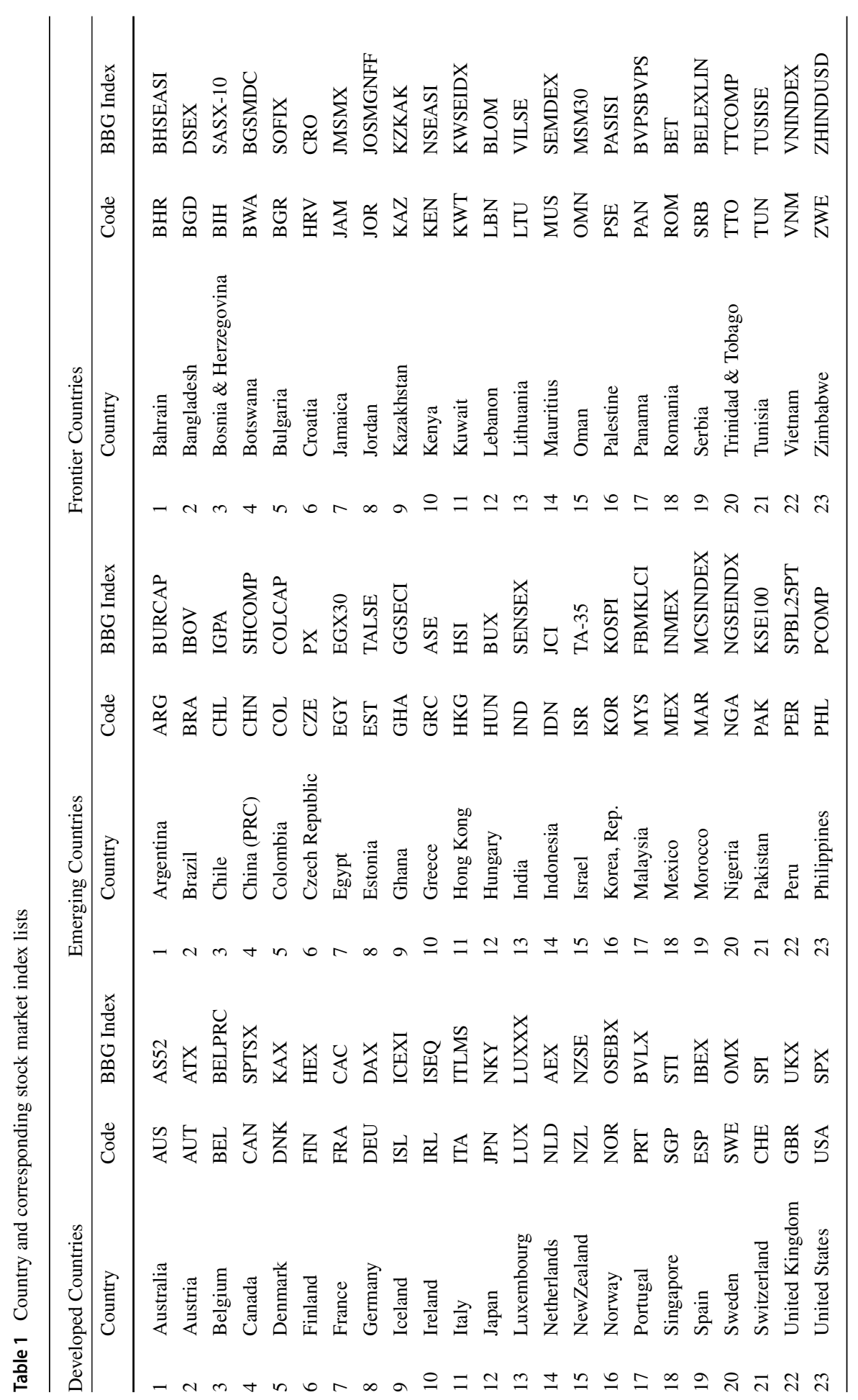




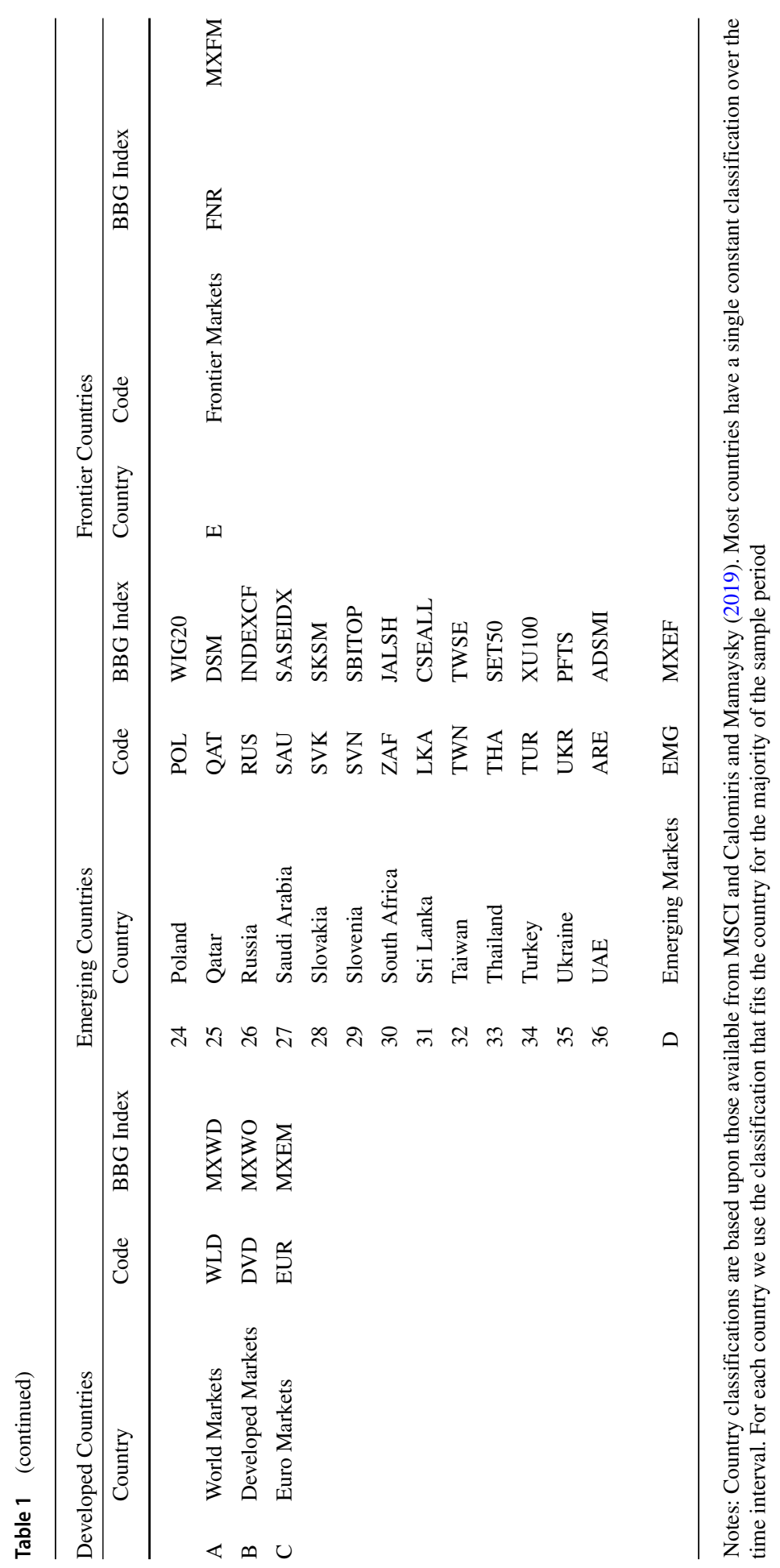


terms, $P_{t}^{U S}$ is the U.S. consumer price index in national currency terms, $\pi_{t}^{U S}$ is the U.S. inflation rate, $e_{t}=\ln E_{t}$ and $t=0$ is the common base year across indexes. That is, the real return to a U.S. resident is the nominal local currency return adjusted for exchange rate appreciation and U.S. inflation. Real returns on the U.S. Treasury Bill, long-term government bonds, and world stock market portfolio are calculated similarly. We note that the real return on the foreign investment to the U.S. resident is equal to the real local currency return, $r_{p}^{n o m}-\pi^{*}$, if relative purchasing power parity (PPP) holds i.e. $\pi^{U S}-\pi^{*}=\Delta e$.

\subsection{Systematic Risk Drivers}

Following our discussion in Section 2.2, we accordingly collect data on some of the potential macroeconomic covariates of beta. Exports and imports of goods and services, market capitalization, international reserves minus gold, ease of doing business indicators and GDP are retrieved from the World Bank's World Development Indicators. Data on stocks of external assets and liabilities are gathered from the updated External Wealth of Nations II repository of Lane and Milesi-Ferretti (2007). Finally, a measure of geographical proximity to the U.S. is obtained from the CEPII Distances database.

We adopt the volume-based measure of international financial integration, reflecting the sum of total external assets and liabilities for each country, from Lane and Milesi-Ferretti (2007). Meanwhile, the sum of import and export flows is employed to define international trade integration in goods and services. Lastly, real and nominal exchange rate volatility are each calculated as the standard deviation of the annual growth rate of the exchange rate over the period of concern.

\section{Empirical Results}

\subsection{CAPM Regressions}

\subsubsection{Long Time Horizons}

For the period 1988-2017, Fig. 1 plots the cross-section of average excess returns on national stock market indexes and 10-year government bonds against the corresponding betas obtained from Eq. 2. The betas in this figure are estimated using the MSCI All Country World Index as the global portfolio. Figure 2 repeats the exercise for the extended time interval 1968-2017 by employing the MSCI Developed Markets Index as a proxy for the global portfolio. Over the common time period, the MSCI world and developed market indexes are highly correlated.

Figures 1 and 2 both indicate a strong positive association between the excess returns and systematic risks of assets in world, developed, emerging and frontier market samples. This salient feature of the graphs stands in stark contrast to the typical evidence proffered by the literature, namely, that CAPM betas bear at best a weak postive relation with excess returns. The graphs highlight that there is significant 

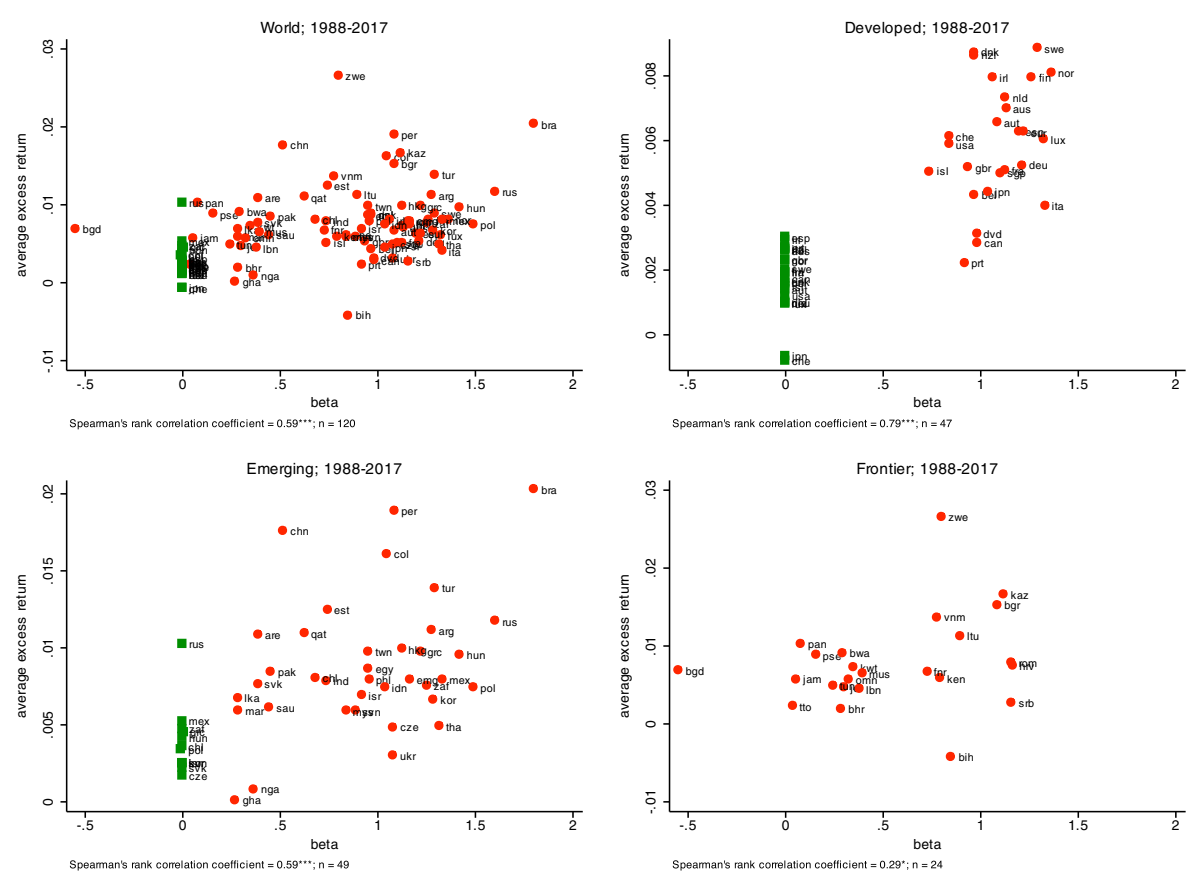

Fig. 1 Average Excess Returns and Systematic Risks, Cross-Sections I. Notes: * significant at 10\%; ** significant at 5\%; *** significant at 1\%. MXWD (MSCI ACWI) is used as the world stock market portfolio. Red circles represent equity while green squares represent long-term government debt

dispersion in country betas, with values ranging from approximately -0.50 to 2 . Moreover, beta estimates across the two figures prove to be quite similar. National markets thus range from those with lower volatility relative to changes in the global portfolio, moving less than one for one with global trends (e.g. equity of Trinidad and Tobago, Ghana), to those that are more volatile than the global market, moving more than one for one with global trends (e.g. equity of Norway, Brazil). As high beta markets are ineffective in reducing the overall variance of an international investment portfolio, they tend to earn higher expected returns. Long-term government bonds, as expected, typically carry the lowest betas, where the former are given by green squares while equities are denoted by red circles in our plots. The removal of these assets however does not adversely affect the rank correlation coefficients of world, developed, and emerging country cohorts, which lie around $0.60,0.80$, and 0.60 respectively. ${ }^{8}$ Overall, the preliminary graphical evidence of pronounced positive correlations suggests that market betas should have significant explanatory power in cross-section regressions.

Table 2 displays the results of the cross-section CAPM regressions (3) for the four aforementioned country cohorts and four different regional portfolios approximating the global portfolio or acting as the benchmark. For each global portfolio proxy, the

\footnotetext{
${ }^{8}$ Parametric Pearson correlations are similar.
} 

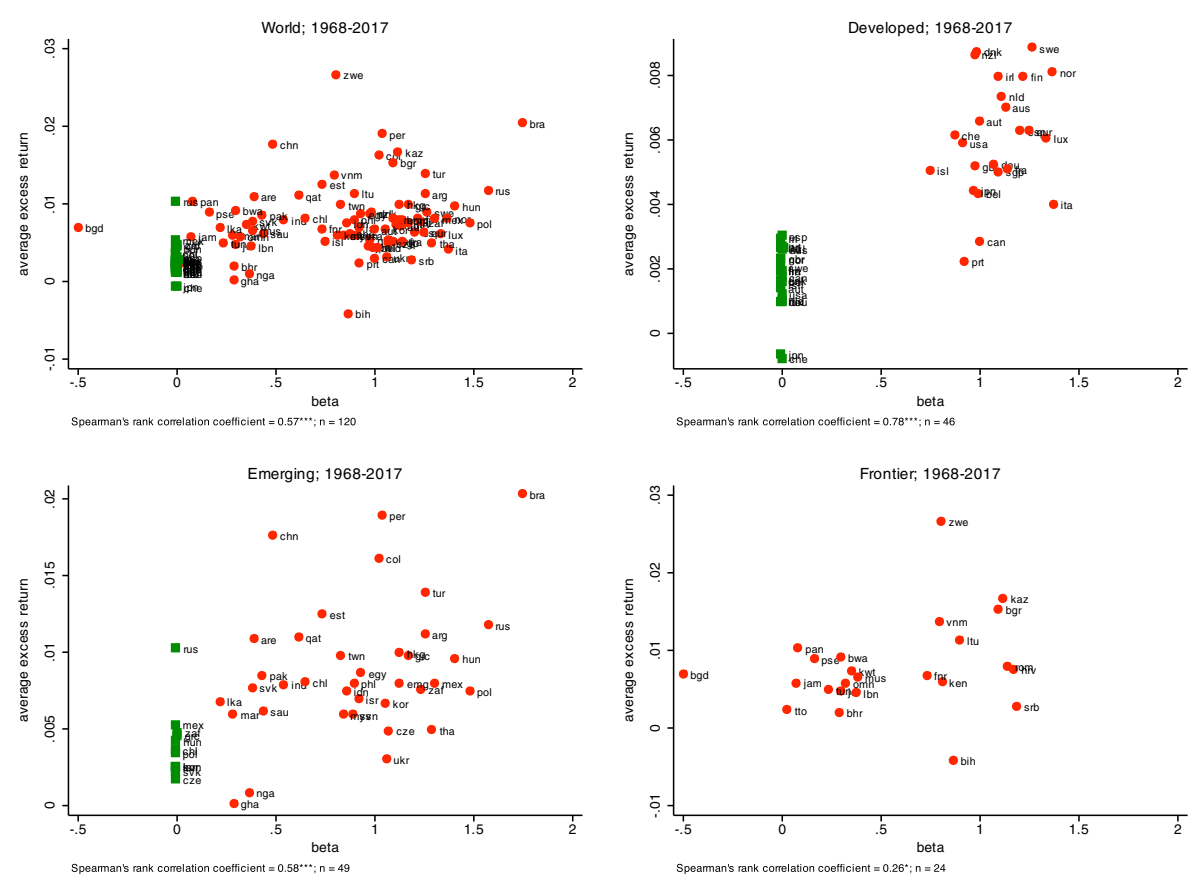

Fig. 2 Average Excess Returns and Systematic Risks, Cross-Sections II. Notes: * significant at 10\%; ** significant at 5\%; *** significant at $1 \%$. MXWO is used as the world stock market portfolio. Red circles represent equity while green squares represent long-term government debt

average excess return observed in the data is reported under the regression results, along with the average risk-free rate for the period.

Panel A of the table uses the MSCI All Country World Index (mxwd) as the global portfolio, and thus is based on the period 1988-2017. The panel shows that market betas have notable explanatory power in most country samples, with the R-squared value reaching as high as 0.63 for developed markets. The estimate of the slope coefficient on beta in the case of world and developed samples falls exactly in line with the average monthly excess global portfolio return of 0.004 (or 0.4 percent) over the period, as predicted by the CAPM. ${ }^{9}$ Such congruency with the slope of the theoretical security market line is practically non-existent in the literature.

At 0.005 , the slope estimate for emerging markets marginally overshoots the average global portfolio risk premium, in contrast to the regular findings of significant undershooting in the literature. We note, however, that an estimate of 0.004 is obtained for this group when government bonds are omitted from the regression. Meanwhile, in the relatively small cohort of frontier markets, the slope estimate of 0.003 marginally undershoots the target, although it narrowly falls short of statistical significance. Despite the latter, at conventional significance levels, additional

\footnotetext{
${ }^{9}$ The annualized rate is approximately 5 percent.
} 
Table 2 Cross-section CAPM regressions: long time horizons

(1)

Sample
(2)

World

Developed

(3)

(4)

A. world portfolio: acwi mxwd

$\begin{array}{ll}\text { Beta } & 0.004^{* * *} \\ & (0.001) \\ \text { Constant } & 0.003^{* * *} \\ & (0.000) \\ \text { Sigma } & 0.004 \\ \text { R-squared } & 0.26\end{array}$

Observations

120

Average excess world portfolio return

Average risk-free rate

$0.004^{* * *}$
$(0.000)$
$0.002^{* * *}$
$(0.000)$
0.002
0.63
47

47

0.004

0.001

B. world portfolio: mxwo

\begin{tabular}{|c|c|c|c|c|}
\hline Beta & $\begin{array}{l}0.004^{* * *} \\
(0.001)\end{array}$ & $\begin{array}{l}0.004^{* * *} \\
(0.000)\end{array}$ & $\begin{array}{l}0.005^{\text {*** }} \\
(0.001)\end{array}$ & $\begin{array}{l}0.003 \\
(0.002)\end{array}$ \\
\hline \multirow[t]{2}{*}{ Constant } & $0.003^{* * *}$ & $0.002^{* * *}$ & $0.004^{* * *}$ & $0.005^{* * *}$ \\
\hline & $(0.000)$ & $(0.000)$ & $(0.001)$ & $(0.001)$ \\
\hline Sigma & 0.004 & 0.002 & 0.004 & 0.006 \\
\hline R-squared & 0.25 & 0.65 & 0.33 & 0.05 \\
\hline Observations & 120 & 46 & 49 & 24 \\
\hline \multicolumn{2}{|c|}{ Average excess world portfolio return } & 0.003 & & \\
\hline \multicolumn{2}{|c|}{ Average risk-free rate } & 0.001 & & \\
\hline \multicolumn{5}{|c|}{ C. world portfolio: mxef } \\
\hline \multirow[t]{2}{*}{ Beta } & $0.007^{* * *}$ & $0.006^{* * *}$ & $0.007^{* * *}$ & 0.004 \\
\hline & $(0.001)$ & $(0.001)$ & $(0.001)$ & $(0.003)$ \\
\hline \multirow[t]{2}{*}{ Constant } & $0.003^{* * *}$ & $0.002^{* * *}$ & $0.003^{* * *}$ & $0.006^{* * *}$ \\
\hline & $(0.000)$ & $(0.000)$ & $(0.001)$ & $(0.001)$ \\
\hline Sigma & 0.004 & 0.002 & 0.004 & 0.006 \\
\hline R-squared & 0.32 & 0.59 & 0.42 & 0.06 \\
\hline Observations & 120 & 47 & 48 & 24 \\
\hline \multicolumn{2}{|c|}{ Average excess world portfolio return } & 0.008 & & \\
\hline \multicolumn{2}{|c|}{ Average risk-free rate } & 0.001 & & \\
\hline \multicolumn{5}{|c|}{ D. world portfolio: $\mathrm{mxfm}$} \\
\hline \multirow[t]{2}{*}{ Beta } & $0.007^{* * *}$ & $0.006^{* * *}$ & $0.007^{* * *}$ & $0.007^{*}$ \\
\hline & $(0.001)$ & $(0.001)$ & $(0.002)$ & $(0.004)$ \\
\hline \multirow[t]{2}{*}{ Constant } & $0.003^{* * *}$ & $0.002^{* * *}$ & $0.003^{* * *}$ & $0.003^{*}$ \\
\hline & $(0.000)$ & $(0.000)$ & $(0.001)$ & $(0.002)$ \\
\hline Sigma & 0.004 & 0.002 & 0.004 & 0.006 \\
\hline R-squared & 0.32 & 0.62 & 0.29 & 0.14 \\
\hline Observations & 120 & 47 & 49 & 23 \\
\hline
\end{tabular}


Table 2 (continued)

\begin{tabular}{lllll}
\hline & $(1)$ & $(2)$ & $(3)$ & $(4)$ \\
Sample & World & Developed & Emerging & Frontier \\
\hline Average excess world portfolio return & 0.007 & \\
Average risk-free rate & 0.000 & \\
\hline
\end{tabular}

Notes: $*$ significant at $10 \%$; ** significant at $5 \%$; *** significant at $1 \%$. Robust standard errors in parentheses. Sigma is the regression standard error

statistical tests (unreported) in each sample still stress that one cannot reject the null hypothesis of a slope coefficient equal to 0.004 .

Intercept estimates are generally larger than the average T-Bill rate in the data (0.001) and these differences tend to be statistically significant, as indicated by excess return regressions. This can arise if investors are only able to borrow at a rate that is higher than the T-Bill rate (Black 1972). We highlight, nevertheless, that the intercept estimate for developed markets (0.002) is relatively close to our average risk-free rate. Furthermore, the intercept estimate in this sample turns out to be consistent with the average risk-free rate when bonds are excluded from the analysis, while the slope coefficient estimate is unaffected. That is, a regression of excess returns on betas yields a statistically insignificant constant term. A perfect fit is thus retrieved in the case of equities alone in the developed markets sample. Figure 3 shows the corresponding security market line.

Panel B of Table 2 employs the MSCI Developed Markets Index (mxwo) as the global or benchmark portfolio and covers the extended period 1968-2017. Results in this panel are virtually identical to those found in panel A, reflecting the high degree of correlation between the aggregate world and developed market portfolios. Panel B deviates from Panel A only with respect to the average excess global portfolio return in the data, which now stands at 0.003 , making the theoretical security market line slightly flatter than before.

In panel $\mathrm{C}$ of the table, the MSCI Emerging Markets Index (mxef) proxies for the global portfolio and results pertain to the interval 1988-2017 as in panel A. The coefficient estimates on beta for world, developed and emerging market samples stand typically around 0.007 , or an annualized rate of approximately 8.7 percent. These point estimates are almost equal to the historical average excess return of 0.008 on the global portfolio proxy. On the other hand, the frontier market sample estimate of 0.004 is marginally statistically insignificant, although one cannot reject the null hypothesis of a 0.008 value. In relation to the intercept term, estimates across the four columns remain relatively similar to those in previous panels. Three of the four samples observe a higher R-squared under the emerging markets global portfolio proxy. Most notably, market betas now explain 42 percent of the variation in emerging market average excess returns (column (3)).

Finally, panel D in Table 2 adopts the MSCI Frontier Markets Index (mxfm) as the global portfolio and spans the period 2002-2017. As in panel C, the slope coefficient estimates lie around 0.007 for world, developed and emerging market groups. 


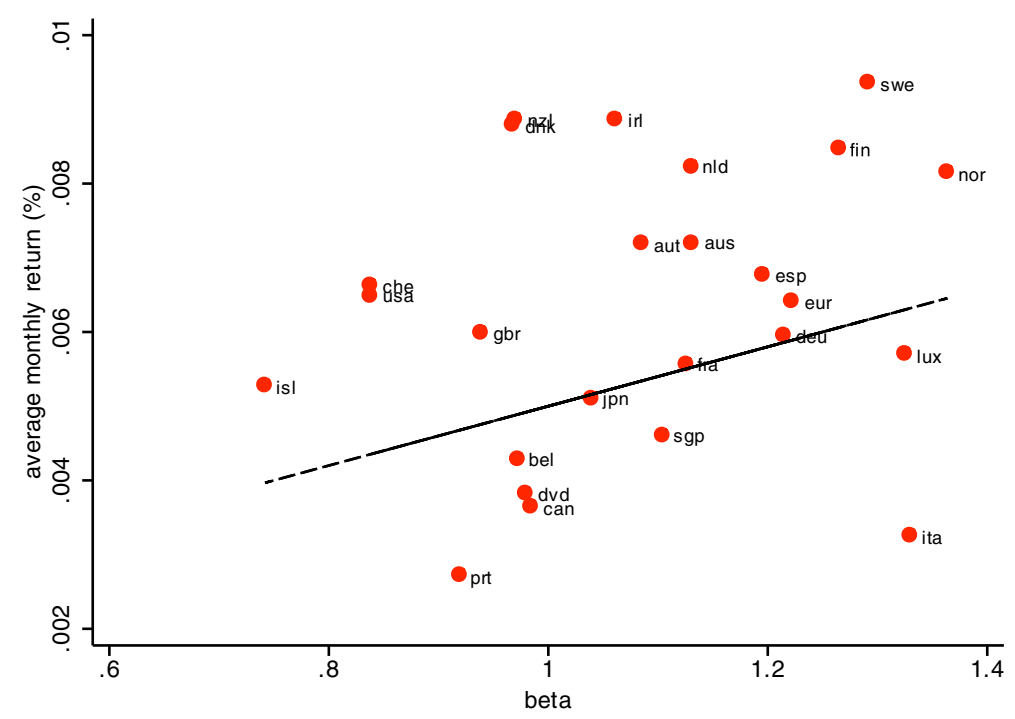

Fig. 3 Empirical Security Market Line, 1988-2017. Notes: Sample consists of developed national stock markets. Global portfolio employed is the MSCI All Country World Index (MXWD). Security market line (SML) plotted is both the empirical and theoretical one. SML has a slope of 0.004, consistent with the average monthly excess return on the world portfolio over the period. When national stock market beta is equal to 0 , SML shows an average monthly return equal to 0.001 , consistent with the average risk-free rate over the period

In addition now, the frontier markets sample generates a statistically significant slope coefficient of 0.007. As can be seen from the panel, these estimates on beta across the four samples tend to be in symmetry with the mean monthly excess return on the global portfolio proxy. Intercept terms still generally suggest overshooting of the average risk-free rate, which is approximately zero during the period. However, this parameter now reaches its peak at 0.003 across columns, with emerging and frontier market samples observing declines in the estimate. The frontier market intercept estimate is in fact borderline statistically significant at the 10 percent level, arguably equating the empirical security market line of the sample with the theoretical one. Relative to previous panels, the R-squared value in the frontier markets sample is higher. Given the CAPM paradigm, Table 2 overall indicates that systematic risk in national financial asset markets, in particular national equity, performs quite well in explaining the cross-country variation in average excess returns on these markets over very long time horizons.

\subsubsection{Short Time Horizons}

Given that the systematic risks of national stock markets can fluctuate over time, we also execute our time series and cross-section CAPM regressions for shorter time horizons. Long-term averages can conceal many pertinent features of the financial landscape. This is especially true when the time horizon is so long that it includes 
substantial changes in the underlying finanical infrastructure, such as institutional and regulatory framework developments.

Taking a closer look at the data, Fig. 4 plots cross-country average excess returns against corresponding market betas for non-overlapping five-year periods. The graphs convey the message that the risk-reward relation is not broadly consistent over the entire sample period. For instance, in the five-year period 2003-2007 immediately prior to the global financial crisis and great recession, we observe a strong positive relation (rank correlation of 0.60 ) between average excess returns on passive
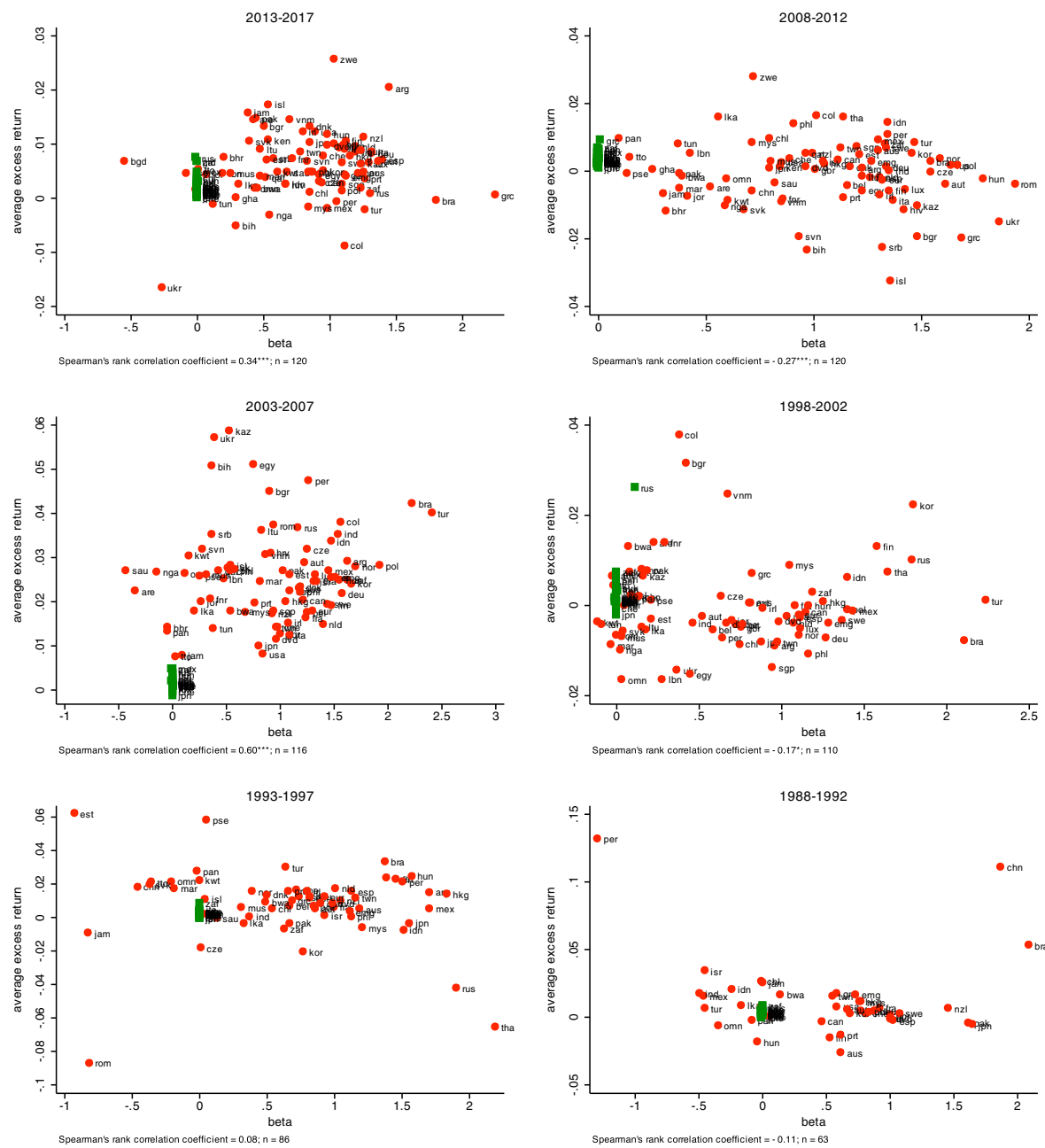

Fig. 4 Average Excess Returns and Systematic Risks, World Cross-Sections for 5-year periods. Notes: * significant at 10\%; ** significant at 5\%; *** significant at 1\%. MXWD (MSCI ACWI) is used as the world stock market portfolio for the period 1988-2017. MXWO proxies for the world stock market over the period 1968-1987. Red circles represent equity while green squares represent long-term government debt 

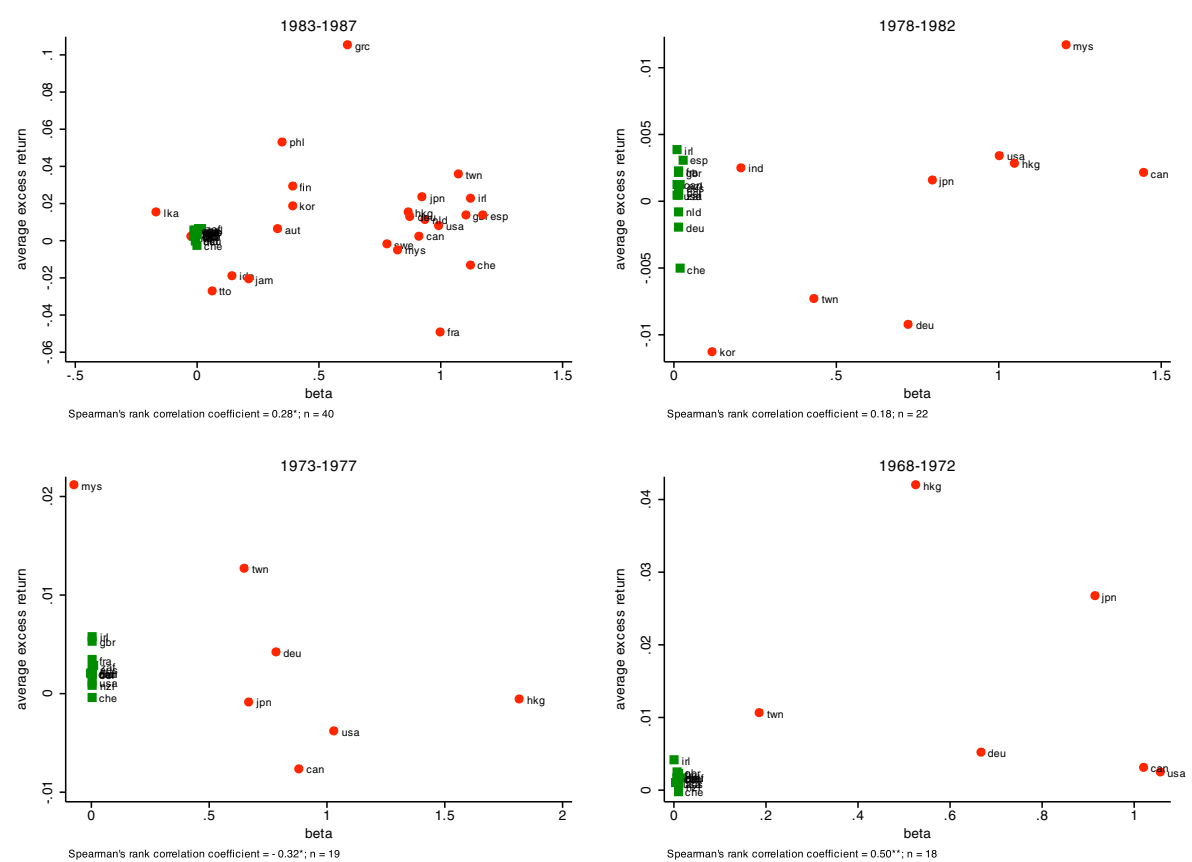

Fig. 4 (continued)

"buy and hold" national stock market indexes and systematic risk. However, this relation turns significantly negative during the recessionary, crisis period of 2008-2012 (rank correlation of -0.27 ), before reverting to significantly positive in the recovery phase of 2013-2017 (rank correlation of 0.34). Other unconventional cases of distinct negative correlations in the graphs include the period 1998-2002 when the dot com bubble burst and 1973-1977 when the first major oil crisis of the decade hit.

Using Fig. 5 we can discern that these episodes of pronounced negative correlations coincide heavily with episodes of large return volatility in the world stock market index. For example, the 2008-2012 interval is characterized by an annualized return volatility level of approximately 21.5 percent, compared to the average level of roughly 14 percent over the full interval 1968-2017. According to the adaptive markets hypothesis, the standard risk-reward nexus can break down during phases of heightened equity volatility. Specifically, large abrupt increases in stock market volatility cause a non-negligible fraction of investors to swiftly lower their holdings through a fight-or-flight response, or, "freaking out". Panic selling during crises places downward pressure on equity prices and upward pressure on the prices of safer assets, as investors reconfigure their portfolios to hold more of the latter. Such dynamics engender a temporary violation of the positive risk-reward relation. Once overreactions subside, the wisdom of the crowds prevails and the standard investment paradigm spawned by the efficient markets hypothesis is restored. Thus, financial markets can be bipolar, featuring excessive downward price spirals at times, but exhibiting normal behavior on most occasions (Lo 2017). 


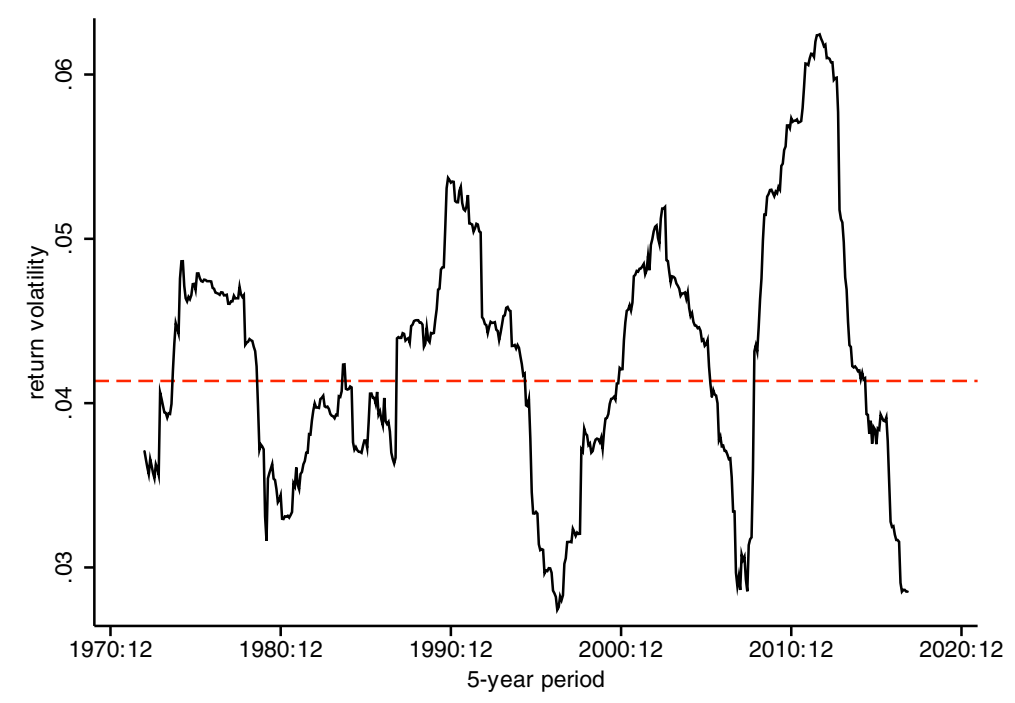

Fig. 5 World Stock Market Index, Rolling 5-year Return Volatility. Notes: The horizontal axis marks the end of each 5-year period. The red dashed line marks the average return volatility over the entire sample period

Another potential explanation for the ostensibly backward relation between risk and reward is the so-called "leverage effect". Deteriorating stock markets inflict negative returns on investors. This produces higher volatility as firms featuring debt in their capital structure are now more highly leveraged. In turn, this can also increase national covariances with the global market. Overall, periodic slumps may not have a significant impact over long time horizons. Although we observe a general upward trend in equities over the very long run (e.g. 50 years), most investors do not adopt such holding positions. Examining shorter five-year horizons can therefore be more informative.

Tables 3, 4 and 5 show the results of cross-section regressions of average returns on market betas for different five-year periods. The MSCI world index (mxwd) is used as the global portfolio over the interval 1988-2017, while the MSCI developed markets index (mxwo) is used as the global portfolio over the interval 1968-1987. Panel C of Table 3 indicates that slope coefficient estimates on beta over the 20032007 period are largely consistent with the corresponding excess global portfolio return of 0.013 . The null hypothesis that 0.013 is the true value cannot be rejected at conventional significance levels across samples. With the exception of developed markets, intercept estimates however significantly overshoot the average real riskfree rate of roughly zero. All country cohorts observe relatively high R-squareds, with the developed group attaining the highest value of 0.82 .

During the period 2008-2012, panel B suggests that riskier assets received a lower return. Deviating significantly from the excess world portfolio return of 0.001 , point slope estimates are -0.004 for world and developed groups, - 0.002 for emerging 
Table 3 Cross-section CAPM regressions: short time horizons I

\begin{tabular}{|c|c|c|c|c|}
\hline & (1) & (2) & (3) & (4) \\
\hline Sample & World & Developed & Emerging & Frontier \\
\hline \multicolumn{5}{|l|}{ A. $2013-2017$} \\
\hline \multirow[t]{2}{*}{ Beta } & $0.004^{* * *}$ & $0.005^{* * *}$ & 0.001 & $0.007^{*}$ \\
\hline & $(0.001)$ & $(0.001)$ & $(0.002)$ & $(0.004)$ \\
\hline \multirow[t]{2}{*}{ Constant } & $0.001^{* * *}$ & $0.000^{* *}$ & 0.002 & $0.003^{*}$ \\
\hline & $(0.001)$ & $(0.000)$ & $(0.002)$ & $(0.002)$ \\
\hline Sigma & 0.005 & 0.003 & 0.006 & 0.006 \\
\hline R-squared & 0.10 & 0.48 & 0.01 & 0.17 \\
\hline Observations & 120 & 47 & 49 & 24 \\
\hline \multicolumn{2}{|c|}{ Average excess world portfolio return } & 0.008 & & \\
\hline \multicolumn{2}{|c|}{ Average risk-free rate } & -0.001 & & \\
\hline \multicolumn{5}{|l|}{ B. $2008-2012$} \\
\hline \multirow[t]{2}{*}{ Beta } & $-0.004^{* * *}$ & $-0.004^{* * *}$ & -0.002 & $-0.009^{* *}$ \\
\hline & $(0.001)$ & $(0.001)$ & $(0.002)$ & $(0.004)$ \\
\hline \multirow[t]{2}{*}{ Constant } & $0.002^{* * *}$ & $0.002^{* * *}$ & $0.003^{* *}$ & 0.002 \\
\hline & $(0.001)$ & $(0.000)$ & $(0.001)$ & $(0.003)$ \\
\hline Sigma & 0.008 & 0.006 & 0.008 & 0.010 \\
\hline R-squared & 0.07 & 0.17 & 0.02 & 0.18 \\
\hline Observations & 120 & 47 & 49 & 24 \\
\hline \multicolumn{2}{|c|}{ Average excess world portfolio return } & 0.001 & & \\
\hline \multicolumn{2}{|c|}{ Average risk-free rate } & -0.001 & & \\
\hline \multicolumn{5}{|l|}{ C. $2003-2007$} \\
\hline \multirow[t]{2}{*}{ Beta } & $0.013^{* * *}$ & $0.015^{* * *}$ & $0.012^{* * *}$ & $0.024^{* * *}$ \\
\hline & $(0.001)$ & $(0.001)$ & $(0.002)$ & $(0.005)$ \\
\hline \multirow[t]{2}{*}{ Constant } & $0.010^{* * *}$ & $0.001^{* *}$ & $0.014^{* * *}$ & $0.018^{* * *}$ \\
\hline & $(0.002)$ & $(0.001)$ & $(0.003)$ & $(0.003)$ \\
\hline Sigma & 0.012 & 0.004 & 0.012 & 0.011 \\
\hline R-squared & 0.32 & 0.82 & 0.35 & 0.32 \\
\hline Observations & 116 & 47 & 48 & 21 \\
\hline \multicolumn{2}{|c|}{ Average excess world portfolio return } & 0.013 & & \\
\hline \multicolumn{2}{|c|}{ Average risk-free rate } & 0.000 & & \\
\hline \multicolumn{5}{|l|}{ D. $1998-2002$} \\
\hline \multirow[t]{2}{*}{ Beta } & $-0.002^{* *}$ & $-0.004^{* * *}$ & -0.000 & $0.038^{* * *}$ \\
\hline & $(0.001)$ & $(0.001)$ & $(0.002)$ & $(0.011)$ \\
\hline \multirow[t]{2}{*}{ Constant } & $0.002^{* *}$ & $0.002^{* * *}$ & 0.003 & -0.001 \\
\hline & $(0.001)$ & $(0.000)$ & $(0.002)$ & $(0.002)$ \\
\hline \multicolumn{2}{|l|}{ Sigma } & & 0.009 & 0.010 \\
\hline \multicolumn{2}{|l|}{ R-squared } & & 0.00 & 0.36 \\
\hline Observations & 110 & 45 & 46 & 18 \\
\hline
\end{tabular}


Table 3 (continued)

\begin{tabular}{lllll}
\hline & $(1)$ & $(2)$ & $(3)$ & $(4)$ \\
Sample & World & Developed & Emerging & Frontier \\
\hline Average excess world portfolio return & -0.004 & & \\
Average risk-free rate & 0.002 & & \\
\hline
\end{tabular}

Notes: $*$ significant at $10 \%$; ** significant at $5 \%$; *** significant at $1 \%$. Robust standard errors in parentheses. Sigma is the regression standard error. Robust regressions employed where appropriate

markets, although statistically insignificant, and -0.009 for frontier markets. Intercept estimates overshoot once again. Overall, R-squared values indicate much lower explanatory power compared to the previous period.

However, in the recovery phase of 2013-2017 following the great recession, the positive return-beta link is restored as shown in panel A. Standing at 0.004 and 0.005 respectively, coefficient estimates on market beta for world and developed groups fall short of the excess global portfolio return of 0.008 . Meanwhile, the frontier markets sample attains a point estimate of 0.007 which cannot be statistically differentiated from the excess world return. Conversely, we find a statistically insignificant estimate on beta of 0.001 for emerging markets. According to relatively recent Geneva reports on the world economy (e.g. Buttiglione et al. 2014), global debt accumulation post financial crisis (2010 in particular) has continued under the stimulus of emerging markets, with notable increases in corporate debt. This may consequently have dampened the standard return-beta nexus for emerging markets in 2013-2017. Intercept estimates lie around zero and are closer to the observed real risk-free rate of -0.001. Moreover, R-squared values are higher for world and developed samples.

Panel D reveals that a negative relation between return and systematic risk generally prevailed over the interval 1998-2002, except in the case of frontier markets. Other than the dot com crash, this period also saw the collapse of Russian financial markets, with devaluations in the national currency and public debt default, which is often viewed as the trigger for the turbulent behavior in global stock markets in 1998. In particular, column (2) indicates that the slope and intercept point estimates for developed markets are perfectly aligned with the average excess global portfolio return of -0.004 and average risk-free rate of 0.002 . For the entire world sample, only the slope estimate is misaligned.

Panels E, G and H of Table 4 show that the relation between beta and return is typically positive across country samples for the periods 1993-1997, 1983-1987 and 1978-1982. In panel E, while the point estimate on beta is 0.005 for the world sample, the corresponding estimate for developed markets falls in line with the mean excess return on the global portfolio of 0.008 . The risk-reward relation breaks down for emerging economies perhaps reflecting the turmoil in Asian and Latin American markets during the period e.g. Hong Kong, Argentina, Mexico in two or more of 1993, 1994, 1997. Meanwhile, intercept estimates tend to overshoot, although not by as much in the case of world and developed samples, and R-squareds are relatively high. In panel G, slope estimates tend to be consistent with the excess global 
Table 4 Cross-section CAPM regressions: short time horizons II

\begin{tabular}{lllll}
\hline & $(1)$ & $(2)$ & $(3)$ & $(4)$ \\
Sample & World & Developed & Emerging & Frontier \\
\hline E. 1993-1997 & & & & \\
Beta & $0.005^{* * *}$ & $0.008^{* * *}$ & -0.012 & 0.050 \\
& $(0.002)$ & $(0.002)$ & $(0.007)$ & $(0.032)$ \\
Constant & $0.006^{* * *}$ & $0.005^{* * *}$ & $0.015^{* * *}$ & 0.016 \\
& $(0.001)$ & $(0.001)$ & $(0.005)$ & $(0.010)$ \\
Sigma & & 0.005 & 0.020 & 0.030 \\
R-squared & & 0.42 & 0.17 & 0.34 \\
Observations & 86 & 44 & 32 & 10 \\
Average excess world portfolio & return & 0.008 & & \\
Average risk-free rate & & 0.002 & & \\
F. 1988-1992 & & & & \\
Beta & -0.001 & $-0.003^{*}$ & -0.001 & $0.048^{* * *}$ \\
& $(0.011)$ & $(0.002)$ & $(0.017)$ & $(0.011)$ \\
Constant & $0.010^{* *}$ & $0.003^{* * *}$ & $0.026^{* *}$ & 0.009 \\
& $(0.005)$ & $(0.001)$ & $(0.011)$ & $(0.005)$ \\
Sigma & 0.024 & 0.007 & 0.037 & 0.011 \\
R-squared & 0.002 & 0.04 & 0.000 & 0.42 \\
Observations & 63 & 37 & 20 & 6 \\
Average excess world portfolio & return & -0.001 & & \\
Average risk-free rate & & 0.002 & & \\
& & & &
\end{tabular}

G. $1983-1987$

$\begin{array}{llll}\text { Beta } & 0.010^{* * *} & 0.010^{* * *} & 0.014 \\ & (0.002) & (0.002) & (0.022) \\ \text { Constant } & 0.006^{* * *} & 0.005^{* * *} & 0.009 \\ & (0.001) & (0.001) & (0.013)\end{array}$

Sigma

R-squared

Observations

40

28

10

Average excess world portfolio return

0.010

Average risk-free rate

0.004

H. 1978-1982

$\begin{array}{llll}\text { Beta } & 0.002 & -0.000 & 0.010 \\ & (0.002) & (0.002) & (0.005) \\ \text { Constant } & 0.001 & 0.002^{* *} & -0.004 \\ & (0.001) & (0.001) & (0.004) \\ \text { Sigma } & 0.005 & 0.004 & 0.007 \\ \text { R-squared } & 0.06 & 0.001 & 0.42 \\ \text { Observations } & 22 & 16 & 6\end{array}$


Table 4 (continued)

\begin{tabular}{lllll}
\hline & $(1)$ & $(2)$ & $(3)$ & $(4)$ \\
Sample & World & Developed & Emerging & Frontier \\
\hline Average excess world portfolio return & -0.002 & & \\
Average risk-free rate & 0.001 & & \\
\hline
\end{tabular}

Notes: $*$ significant at $10 \%$; ** significant at $5 \%$; *** significant at $1 \%$. Robust standard errors in parentheses. Sigma is the regression standard error. Robust regressions employed where appropriate

portfolio return of 0.010 , while intercept estimates are quite close to the risk-free rate of 0.004 . In fact, at standard significance levels across samples, normally one cannot reject the null hypotheses that slope and intercept parameters are 0.010 and 0.004 respectively. Panel H predominantly displays statistically insignificant coefficient estimates. Across all columns for 1978-1982, hypothesis testing (at 5 percent level) is unable to statistically distinguish between the slope coefficient and the period-average world portfolio excess return, or the intercept and the period-average risk-free rate.

Finally, Table 5 gives results for the periods 1973-1977, representing the effective start of the post-Bretton Woods international monetary order, and 1968-1972. For the first of these intervals, Panel I reveals that there is a negative link between systematic risk and return across country samples, with slope estimates lying around the average excess global portfolio return of -0.007 . Indeed, in all cases, one cannot reject the null hypothesis that the slope parameter is -0.007 . Intercept estimates, nevertheless, overshoot the average risk-free rate. For the second time interval, panel J highlights a positive risk-reward relation, with slope estimates falling below the excess world portfolio return. In contrast, intercept estimates lie slightly above the average riskfree rate.

\subsection{Systematic Risk in National Stock Markets}

Table 6 shows the discrepancies in equity systematic risks across developed, emerging and frontier markets over full time intervals. Regardless of the global portfolio used, panels A-D indicate that frontier markets exhibit the lowest betas. Employing the world and developed market indexes respectively as proxies for the global portfolio, panels A and B report median (mean) betas of around 1.09 (1.08) for developed markets, 0.94 (0.92) for emerging markets, and $0.38(0.54)$ for frontier markets. As column (5) of the table shows, these differences are statistically significant. Interestingly, we find some evidence of a negative unconditional relation between geographical distance from the U.S. and beta. ${ }^{10}$ The link may indicate that countries further away from the main actor on the world stage are less exposed to contagion effects from the region. This may be related to weaker financial and trade

\footnotetext{
${ }^{10}$ Gross rank correlation coefficient of -0.20 that is statistically significant at the 10 percent level.
} 
Table 5 Cross-section CAPM regressions: short time horizons III

\begin{tabular}{lllll}
\hline & $(1)$ & $(2)$ & $(3)$ & $(4)$ \\
Sample & World & Developed & Emerging & Frontier \\
\hline I. 1973-1977 & & & & \\
Beta & $-0.004^{*}$ & $-0.007^{* * *}$ & -0.007 & $(0.005)$ \\
& $(0.002)$ & $(0.002)$ & 0.012 \\
Constant & $0.003^{*}$ & 0.001 & $(0.008)$ \\
& $(0.002)$ & $(0.001)$ & 0.010 \\
Sigma & 0.006 & & 0.38 \\
R-squared & 0.11 & & 6 \\
Observations & 19 & 15 & \\
Average excess world portfolio return & -0.007 & \\
Average risk-free rate & & -0.001 & \\
J. 1968-1972 & & & \\
Beta & & & \\
& $0.002^{*}$ & $0.002^{*}$ & \\
Constant & $(0.001)$ & $(0.001)$ & \\
Sigma & $0.002^{* * *}$ & $0.002^{* * *}$ & \\
R-squared & $(0.000)$ & $(0.000)$ & \\
Observations & & & \\
Average excess world portfolio return & & & \\
Average risk-free rate & & 15 & \\
\hline
\end{tabular}

Notes: * significant at $10 \%$; ** significant at $5 \%$; *** significant at $1 \%$. Robust standard errors in parentheses. Sigma is the regression standard error. Robust regressions employed where appropriate

linkages with the U.S. as a result of larger information asymmetries or transportation costs.

With the emerging markets global portfolio proxy, panel $\mathrm{C}$ also displays statistically significant differences. However, median and mean betas across samples are now lower, with frontier markets characterized by a median beta of 0.25 compared to the high of 0.75 for emerging markets. Using the frontier markets index as the global portfolio, panel D indicates similar patterns although group differences are no longer statistically significant. Median beta for frontier markets now stands at 0.61 .

Providing an intertemporal decomposition, Table 7 examines country group betas over shorter time horizons of five years. World and developed market indexes are used as the global portfolio, with panels A-F using the former and panels G-J using the latter. We find that frontier stock markets display the lowest levels of systematic risk in each period, while developed stock markets are typically at the other end of the spectrum. Differences across country cohorts in each period tend to be statistically significant. 
Table 6 Systematic risks: long time horizons

\begin{tabular}{llllll}
\hline Equity & $(1)$ & $(2)$ & $(3)$ & $(4)$ & $(5)$ \\
& World & Developed & Emerging & Frontier & Test of Equality \\
\hline
\end{tabular}

A. world portfolio: acwi mxwd

$\begin{array}{llllll}\text { Mean } & 0.87 & 1.08 & 0.94 & 0.54 & 0.000 \\ \text { Median } & 0.96 & 1.09 & 0.96 & 0.39 & 0.000 \\ \text { Observations } & 86 & 25 & 37 & 24 & 86\end{array}$

B. world portfolio: dm mxwo

$\begin{array}{llllll}\text { Mean } & 0.85 & 1.09 & 0.90 & 0.55 & 0.000 \\ \text { Median } & 0.95 & 1.09 & 0.92 & 0.38 & 0.000 \\ \text { Observations } & 86 & 24 & 37 & 24 & 85\end{array}$

C. world portfolio: em mxef

$\begin{array}{llllll}\text { Mean } & 0.58 & 0.60 & 0.72 & 0.36 & 0.000 \\ \text { Median } & 0.58 & 0.59 & 0.75 & 0.25 & 0.007 \\ \text { Observations } & 86 & 25 & 36 & 24 & 85\end{array}$

D. world portfolio: fm mxfm

$\begin{array}{llllll}\text { Mean } & 0.67 & 0.68 & 0.72 & 0.58 & 0.127 \\ \text { Median } & 0.70 & 0.69 & 0.71 & 0.61 & 0.252 \\ \text { Observations } & 86 & 25 & 37 & 23 & 85\end{array}$

Notes: P-values reported for tests of equality in column (5). $\mathrm{F}^{*}$-test used for test of equal sub-group means. Mood's median test used for test of equal sub-group medians. In corresponding order, panels A, B, C and D pertain to the time intervals 1988-2017, 1968-2017, 1988-2017 and 2002-2017 respectively

Frontier markets observe the lowest level of systematic risk during 1993-1997, with a median beta of approximately -0.01 . Conversely, they are exposed to the highest level of systematic risk during 2008-2012, with a median beta of approximately 0.72 . Similarly, the median beta for developed markets is also highest, at 1.30 , in 2008-2012. The lowest beta, on the other hand, for this group is found during 19731977. The relatively stronger betas of advanced economies, particularly in more recent times, can partly be attributed to the harmonization of national risk appetites, arising from the transmission effects induced by monetary policy in global financial centres (Jordà et al. 2018). Meanwhile, emerging market median betas range from 0.36 over the period $1968-1972$ to 1.19 over 2003-2007. Tests of mean and median equality over time for each country group, including the full world sample, point to statistically significant intertemporal differences in betas.

Lastly, assessing the means and medians of pooled five-year estimates over 19682017, the bottom of Table 7 shows results consistent with panels A and B of Table 6. Developed markets carry the highest equity betas, followed by emerging, and then frontier markets. Markets that are counter cyclical or less correlated with global trends may be viewed as desirable investment opportunities because they help to reduce return volatility, and thus smooth the consumption path. That is, assets that pay well during bad times act as a good hedge and so will be in demand. More generally, our results suggest that investment or fund managers not mimicking the 
Table 7 Systematic risks: short time horizons

\begin{tabular}{llllll}
\hline Equity & $(1)$ & $(2)$ & $(3)$ & $(4)$ & $(5)$ \\
& World & Developed & Emerging & Frontier & Test
\end{tabular}

(5)

A. 2013-2017

$\begin{array}{llllll}\text { Mean } & 0.82 & 1.11 & 0.88 & 0.42 & 0.000 \\ \text { Median } & 0.87 & 1.12 & 0.87 & 0.44 & 0.000 \\ \text { Observations } & 86 & 25 & 37 & 24 & 86\end{array}$

B. $2008-2012$

$\begin{array}{llllll}\text { Mean } & 1.05 & 1.22 & 1.10 & 0.77 & 0.001 \\ \text { Median } & 1.14 & 1.30 & 1.14 & 0.72 & 0.014 \\ \text { Observations } & 86 & 25 & 37 & 24 & 86\end{array}$

C. 2003-2007

Mean

$\begin{array}{lllll}0.92 & 1.14 & 1.06 & 0.41 & 0.000 \\ 0.96 & 1.18 & 1.19 & 0.37 & 0.000 \\ 82 & 25 & 36 & 21 & 82\end{array}$

Observations

D. 1998-2002

$\begin{array}{llllll}\text { Mean } & 0.70 & 0.93 & 0.84 & 0.14 & 0.000 \\ \text { Median } & 0.70 & 0.97 & 0.75 & 0.10 & 0.000 \\ \text { Observations } & 77 & 24 & 35 & 18 & 77\end{array}$

E. 1993-1997

Mean

$\begin{array}{ll}0.70 & 0.89 \\ 0.77 & 0.88 \\ 61 & 22\end{array}$

0.85

$-0.13 \quad 0.000$

Observations

$61 \quad 22$

F. 1988-1992

Mean
Median
Observations

G. 1983-1987

Mean
Median
Observations

$\begin{array}{ll}0.52 & 0.89 \\ 0.62 & 0.88 \\ 42 & 17\end{array}$

0.85

$-0.01$

0.002

29

10

61

H. 1978-1982

Mean

Observations

I. 1973-1977

$\begin{array}{llllll}\text { Mean } & 0.83 & 0.85 & 0.80 & & 0.946 \\ \text { Median } & 0.79 & 0.84 & 0.66 & 0 & 0.270 \\ \text { Observations } & 7 & 4 & 3 & & 7 \\ \text { J. } 1968-1972 & & & & 0.132 \\ \text { Mean } & 0.73 & 0.92 & 0.36 & 0.083 \\ \text { Median } & 0.79 & 0.97 & 0.36 & 0 & 6\end{array}$


Table 7 (continued)

\begin{tabular}{llllll}
\hline Equity & $(1)$ & $(2)$ & $(3)$ & $(4)$ & $(5)$ \\
& World & Developed & Emerging & Frontier & $\begin{array}{l}\text { Test of Equality } \\
\text { Test of Equality Over Time }\end{array}$ \\
$\begin{array}{l}\text { Means } \\
\text { Medians }\end{array}$ & 0.000 & 0.000 & 0.014 & 0.000 & \\
1968-2017, panel over 5-year intervals & 0.006 & 0.003 & 0.005 & 0.000 & \\
Mean & 0.81 & 1.02 & 0.86 & 0.36 & 0.000 \\
Median & 0.86 & 1.01 & 0.86 & 0.30 & 0.000 \\
Observations & 479 & 163 & 212 & 104 & 479 \\
\hline
\end{tabular}

Notes: P-values reported for tests of equality in column (5) and Test of Equality Over Time. F*-test used for test of equal sub-group/period means. Mood's median test used for test of equal sub-group/period medians

global portfolio should target developed countries in order to maintain a relatively aggressive portfolio, and developing markets for a more defensive portfolio.

\subsection{Performance}

Figure 6 summarizes general stock market performance for each country over the sample period by plotting average and median five-year Sharpe ratios and Morningstar risk-adjusted returns. The Sharpe ratio is the reward-to-variability ratio, defined as $\left(\bar{r}_{p}-\bar{r}_{f}\right) / \sigma_{p}$. The Morningstar rating on the other hand can be interpreted as the risk-free equivalent excess return for an investor with a level of risk aversion $\gamma$. Specifically, with annualized values, it is defined as $\left[T^{-1} \sum_{t=1}^{T}\left[\left(1+r_{p, t}\right)(1+\right.\right.$ $\left.\left.\left.r_{f, t}\right)^{-1}\right]^{-\gamma}\right]^{-12 / \gamma}-1$. In line with the literature, we set $\gamma=2$.

The graphs indicate that the two general performance indicators are highly correlated, with parametric and non-parametric correlations in excess of 0.50 . Notably, the graphs suggest that frontier stock markets are typically among the better performers in our sample. ${ }^{11}$ We find pooled median 5-year Sharpe ratios of 0.29, 0.27 and 0.47 for developed, emerging and frontier markets over the full period, where the data are annualized. Looking at pooled median 5-year Morningstar returns over the same time horizon, we obtain corresponding values of $0.004,-0.053$ and 0.036 respectively. These group differences are statistically significant.

However, Jensen's alpha, which is defined as the average return on the national stock market index over and above that predicted by the CAPM, does not suggest that frontier markets are systematically better performers. ${ }^{12}$ Figure 7 shows that 5 -year alphas across countries and over time tend to be clustered around zero. Figure 8 in

\footnotetext{
${ }^{11}$ Quite similar patterns are found over the shorter interval 1988-2017 too.

${ }^{12}$ That is, Jensen's alpha can be obtained as the intercept from time series regression (2).
} 

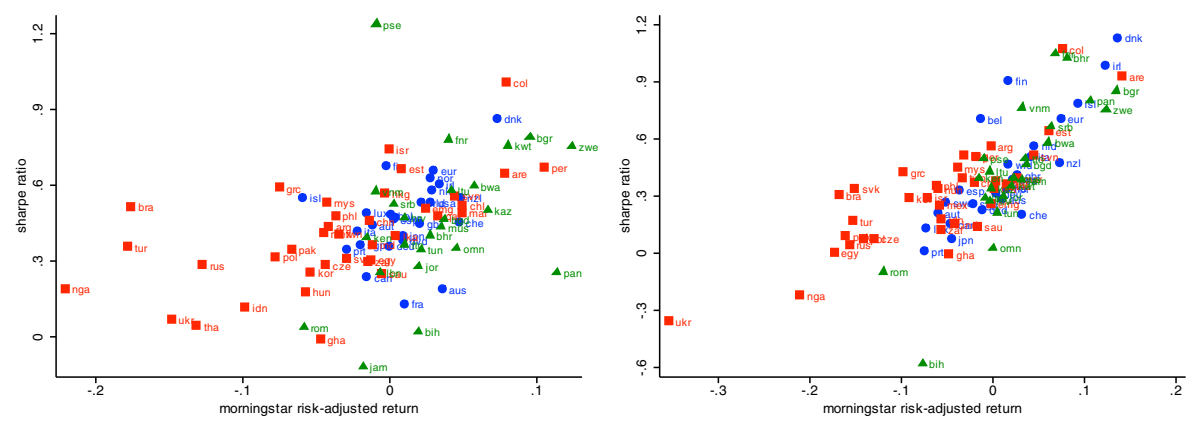

Fig. 6 Average (left) and Median (right) 5-Year Performance Indicators, 1968-2017. Notes: Blue circles, red squares, and green triangles correspond to developed, emerging, and frontier stock markets respectively. Annualized figures are shown

turn plots 5-year alphas against 5-year betas across countries over the entire sample period. In contrast to previous studies, the graph suggests that countries with higher levels of non-diversifiable stock market risk are not systematically associated with negative alphas. In particular, we find that the median beta across countries with positive alphas is 0.84 , while it is 0.94 across countries with negative alphas, with this discrepancy being statistically insignificant at the 10 percent level. As the graph illustrates, there does not appear to be an unequivocally strong inverse relation between alpha and beta.

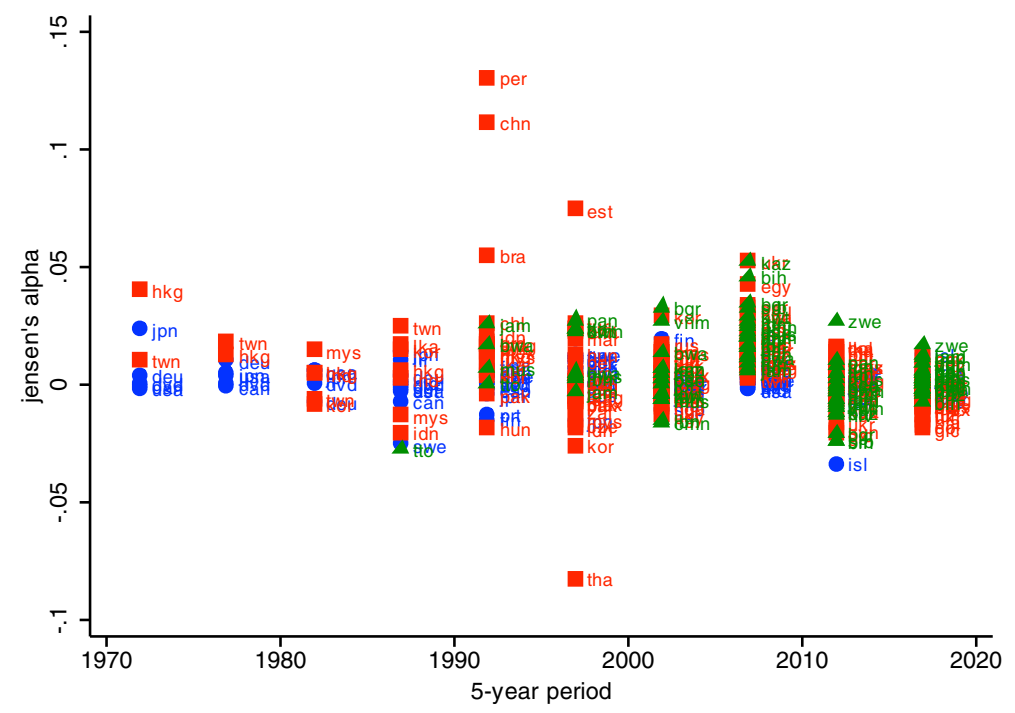

Fig. 7 5-Year Alphas. Notes: Blue circles, red squares, and green triangles correspond to developed, emerging, and frontier stock markets respectively. The horizontal axis marks the final year of each nonoverlapping 5-year period. Jensen's alpha is the average return on the national stock market portfolio over and above that predicted by the CAPM 


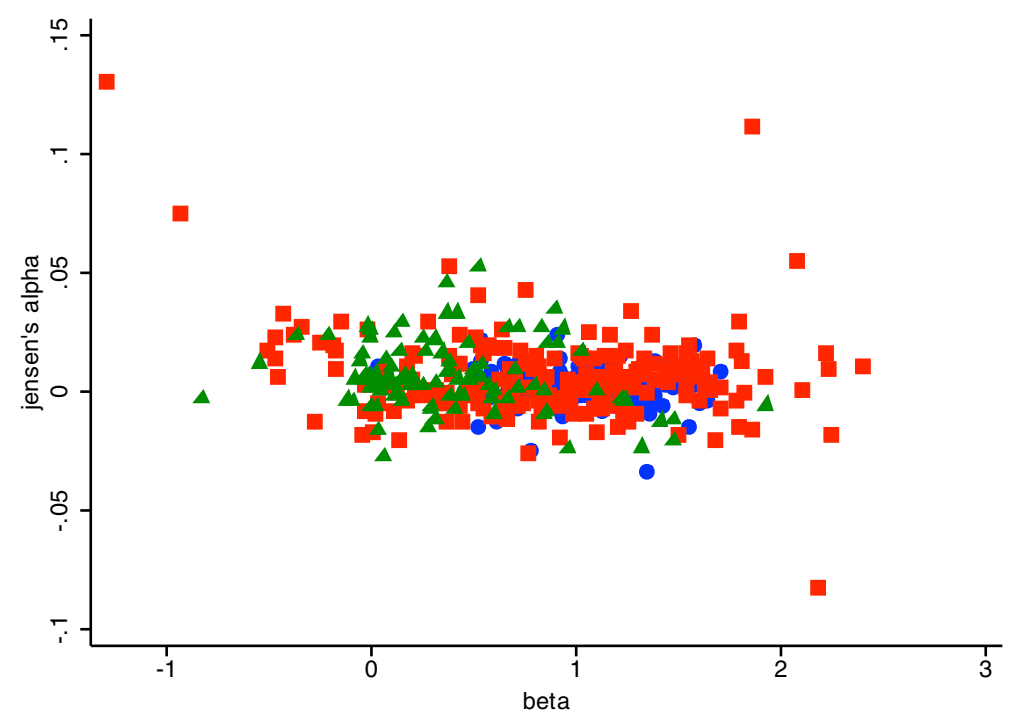

Fig. 8 Alphas vs Betas. Notes: Blue circles, red squares, and green triangles correspond to developed, emerging, and frontier stock markets respectively. 5-year alphas and betas are employed. Jensen's alpha is the average return on the national stock market portfolio over and above that predicted by the CAPM. Parametric and non-parametric correlations between alpha and beta are close to zero

\subsection{Betas and Covariates}

Examining the macroeconomic covariates of national equity betas in a longitudinal setup, Table 8 provides the results of fixed effects and pooled OLS panel regressions using five-year data. ${ }^{13}$ Betas in columns (1)-(3) are based on the all-country world portfolio (acwi mxwd), with regressions corresponding to the interval 1988-2017. Betas in columns (4)-(6) meanwhile are based on the developed markets world portfolio proxy, with regressions corresponding to the 1968-2017 interval. Panel A of the table employs nominal exchange rate volatility in the specifications, while panel B uses real exchange rate volatility instead. Financial openness, trade openness, market capitalization, and international reserves are employed as fractions of national GDP i.e. period-average ratios.

The core fixed effects panel regressions of Table 8 (columns (1) and (4)) show that financial and trade openness have relatively strong positive links with national stock market betas. The parameter estimates are all statistically significant at one or more of the conventional levels. In panel A of the table, the estimated coefficients on financial openness stand around 0.21 . This implies that a 10 percent increase in financial openness (i.e. percentage change in variable) is associated with a 0.021 increase in beta. In panel $\mathrm{B}$, the comparable average estimate is 0.39 . Trade openness coefficient estimates are quite sizable in fixed effects regressions. The average estimate

\footnotetext{
${ }^{13}$ Qualitatively, in a less refined preliminary approach, non-parametric gross (unconditional) correlation coefficients over the cross section mostly yielded similar results.
} 
Table 8 5-year panel regressions

\begin{tabular}{|c|c|c|c|c|c|c|}
\hline \multirow[t]{4}{*}{ World portfolio: } & \multicolumn{3}{|c|}{ acwi mxwd } & \multicolumn{3}{|c|}{ dm mxwo } \\
\hline & (1) & (2) & (3) & (4) & (5) & (6) \\
\hline & Fixed & Pooled & Pooled & Fixed & Pooled & Pooled \\
\hline & Effects & OLS I & OLS II & Effects & OLS I & OLS II \\
\hline \multicolumn{7}{|l|}{ A. } \\
\hline \multirow[t]{2}{*}{ Financial openness } & $0.216^{* * *}$ & -0.019 & -0.006 & $0.210^{* * *}$ & -0.012 & 0.010 \\
\hline & $(0.069)$ & $(0.042)$ & $(0.042)$ & $(0.080)$ & $(0.040)$ & $(0.040)$ \\
\hline \multirow[t]{2}{*}{ Trade openness } & $0.877^{* *}$ & 0.067 & 0.133 & $0.783^{* *}$ & 0.084 & $0.160^{*}$ \\
\hline & $(0.378)$ & $(0.098)$ & $(0.104)$ & $(0.387)$ & $(0.095)$ & $(0.100)$ \\
\hline \multirow[t]{2}{*}{ Market cap. } & $0.150^{* *}$ & $0.074^{* *}$ & $0.084^{* *}$ & $0.177^{* *}$ & $0.092^{* * *}$ & $0.112^{* * *}$ \\
\hline & $(0.075)$ & $(0.038)$ & $(0.041)$ & $(0.077)$ & $(0.035)$ & $(0.037)$ \\
\hline \multirow[t]{2}{*}{ Relative gdp } & $0.552^{*}$ & $0.151^{* * *}$ & $0.148^{* * *}$ & $0.564^{* *}$ & $0.147^{* * *}$ & $0.134^{* * *}$ \\
\hline & $(0.323)$ & $(0.026)$ & $(0.025)$ & $(0.283)$ & $(0.025)$ & $(0.024)$ \\
\hline \multirow[t]{2}{*}{ Reserves } & $-1.207^{*}$ & -0.135 & -0.095 & $-1.286^{*}$ & -0.168 & -0.113 \\
\hline & $(0.701)$ & $(0.157)$ & $(0.154)$ & $(0.688)$ & $(0.161)$ & $(0.158)$ \\
\hline \multirow[t]{2}{*}{ Exchange rate vol. I } & -0.019 & $0.050^{* * *}$ & $0.047^{* * *}$ & -0.024 & $0.047^{* * *}$ & $0.044^{* * *}$ \\
\hline & $(0.054)$ & $(0.019)$ & $(0.016)$ & $(0.050)$ & $(0.018)$ & $(0.015)$ \\
\hline Time dummies & yes & yes & no & yes & yes & no \\
\hline Within R-squared & 0.38 & & & 0.41 & & \\
\hline Between R-squared & 0.25 & & & 0.27 & & \\
\hline Overall R-squared & 0.16 & 0.33 & 0.22 & 0.17 & 0.35 & 0.22 \\
\hline \multicolumn{7}{|l|}{ B. } \\
\hline \multirow[t]{2}{*}{ Financial openness } & $0.340^{*}$ & -0.031 & 0.008 & $0.429^{* *}$ & -0.022 & 0.016 \\
\hline & $(0.210)$ & $(0.055)$ & $(0.052)$ & $(0.214)$ & $(0.055)$ & $(0.051)$ \\
\hline \multirow[t]{2}{*}{ Trade openness } & $0.791^{* *}$ & $0.196^{*}$ & $0.232^{* *}$ & $0.556^{*}$ & $0.208^{* *}$ & $0.249^{* *}$ \\
\hline & $(0.331)$ & $(0.110)$ & $(0.110)$ & $(0.326)$ & $(0.108)$ & $(0.109)$ \\
\hline \multirow[t]{2}{*}{ Market cap. } & $0.145^{*}$ & $0.093^{* *}$ & $0.072^{*}$ & $0.160^{*}$ & $0.097^{* * *}$ & $0.076^{*}$ \\
\hline & $(0.089)$ & $(0.041)$ & $(0.043)$ & $(0.088)$ & $(0.038)$ & $(0.041)$ \\
\hline \multirow[t]{2}{*}{ Relative gdp } & $0.878^{* * *}$ & $0.109^{* * *}$ & $0.138^{* * *}$ & $0.813^{* * *}$ & $0.111^{* * *}$ & $0.143^{* * *}$ \\
\hline & $(0.255)$ & $(0.033)$ & $(0.031)$ & $(0.275)$ & $(0.033)$ & $(0.031)$ \\
\hline \multirow[t]{2}{*}{ Reserves } & -0.444 & $-0.598^{* * *}$ & $-0.397^{* *}$ & -0.418 & $-0.644^{* * *}$ & $-0.423^{* *}$ \\
\hline & $(0.686)$ & $(0.199)$ & $(0.191)$ & $(0.688)$ & $(0.193)$ & $(0.190)$ \\
\hline \multirow[t]{2}{*}{ Exchange rate vol. II } & $0.095^{* *}$ & $0.145^{* *}$ & $0.145^{* *}$ & $0.117^{* *}$ & $0.135^{* *}$ & $0.133^{* *}$ \\
\hline & $(0.050)$ & $(0.062)$ & $(0.063)$ & $(0.053)$ & $(0.059)$ & $(0.059)$ \\
\hline Time dummies & yes & yes & no & yes & yes & no \\
\hline Within R-squared & 0.48 & & & 0.48 & & \\
\hline Between R-squared & 0.19 & & & 0.21 & & \\
\hline Overall R-squared & 0.12 & 0.29 & 0.21 & 0.12 & 0.31 & 0.23 \\
\hline
\end{tabular}

Notes: * significant at $10 \%$; ** significant at 5\%; *** significant at $1 \%$. Robust standard errors in parentheses. Dependent variable is the national stock market beta. Exchange rate vol. I (II) is nominal bilateral (real multilateral) exchange rate volatility. Friedman (1937), Frees (1995), and Pesaran (2004) tests fail to reject the null hypothesis of cross-sectional independence in relevant regressions 
across the four specifications suggests that a 10 percent increase in trade openness is related to a 0.075 increase in beta, which is over twice as much as the typical effect of a similar increase in international financial integration. Although they are smaller, trade openness coefficients remain positive and mostly statistically significant in pooled regressions. The results suggest that enhanced cross-border financial and trade linkages induce higher comovements across countries. ${ }^{14}$

Reflecting financial or economic size and development, market capitalization and relative-to-world GDP are statistically significant covariates across all specifications in both panels of the table. Unequivocally, all estimates point to a positive association between each of these variables and beta, with relative GDP having a more pronounced relation. Pooled regressions, however, yield slope estimates that are less economically significant. Bigger economic players can impart far-reaching effects more regularly. For instance, larger developed markets, especially global financial centres, are likely to covary more with world markets through national monetary policy spillovers or familiarity bias in the international portfolios of foreign investors. Local events in developing markets by contrast are less likely to have the ubiquitous effects that induce such comovements.

Our estimates suggest an inverse link between international reserves and systematic risk in national stock markets. In panel A, within-regression estimates for reserves of around -1.25 are much larger in absolute terms than corresponding pooled estimates, although the latter are statistically insignificant. In panel B, on the other hand, all slope coefficients on reserves are relatively similar in size. They average around -0.49 , but only pooled estimates are statistically significant. Overall, our results suggest that international reserves assist in insulating national markets against foreign shocks, thereby decoupling domestic and foreign output and equity movements.

In almost all specifications, higher exchange rate volatility is associated with a higher equity beta. This result is consistent with Bordo and Helbling (2003) who find that fixing the exchange rate does not enhance output synchronization across countries. Moreover, recent research finds that, post 1945, the transmission effects of financial centre monetary policy are sizable under floats, leading to an increased synchronization of national risk appetites that bind equity markets together (Jordà et al. 2018). In panel $B$ of the table, coefficients on real effective exchange rate volatility across columns are all positive and statistically significant at the 5 percent level. The estimates are similar in magnitude with a typical value of 0.13 , implying that a 10 percent increase in real exchange rate volatility contributes to a 0.013 increase in beta. For bilateral nominal exchange rate volatility in panel A, pooled estimates are clustered around 0.05 and are statistically significant at the 1 percent level. Conversely, corresponding estimates in fixed effects regressions are indifferent from zero.

\footnotetext{
${ }^{14}$ Economies in which it is easier to conduct business, as a result of greater political stability or less rigid regulation for example, are expected to have more pronounced global ties through higher levels of international portfolio investment, foreign direct investment etc. Importantly, better business environments are more conducive to success among domestic firms, that, building on their foundations, can go on to compete on the world stage with their exports. Over the cross section, we find a strong positive relation between market betas and ease-of-doing business rankings.
} 
The primary reason for the discrepancy between pooled and within estimates of volatility coefficients in panel $\mathrm{A}$ is that the nominal exchange rate exhibits much greater variation across countries than over time for individual countries. For example, certain peggers in the Middle East observe virtually zero nominal exchange rate volatility over the sample period. Put differently, given that pooled regressions focus on between-country variation, while fixed effects regressions focus on within-country variation, the former are better suited to capturing the role of nominal exchange rate volatility. In summary, our estimates are consistent with the notion that lower nominal exchange rate volatility raises consensus among domestic investors about the likely direction of home fundamentals, thereby attenuating the need to look abroad for guidance, and thus cross-border comovements.

\section{Conclusions}

Employing national stock market prices across the globe, this paper finds that the basic CAPM performs much better than documented in the literature. At shorter time horizons we also obtain evidence indicating that the positive risk-reward relation can break down during times of high volatility, as suggested by the adaptive markets hypothesis. Relative to advanced and emerging markets, our results point to lower systematic risk in frontier equity markets. General return indicators moreover reveal that frontier stock markets have on average fared better than more developed ones, while the relation between alphas and betas across countries is quite flat.

We next investigate the macroeconomic covariates of national stock market betas. Our results show that countries characterized by higher levels of financial and trade openness, exchange rate volatility, and larger economic size feature greater systematic risk in their equity markets. On the other hand, by protecting the economy from external pressures, international reserves are found to attenuate the systematic link between national and world stock markets. Our findings suggest that with increasing trade globalization, the transmitted effects of country-specific developments are likely to be more profoundly felt in foreign markets. Such integration into the world economy in addition implies a reduction in the benefits of portfolio diversification across countries.

\section{References}

Ahn S, Perez MF, Gadarowski C (2013) Two-Pass Estimation of risk premiums with multicollinear and Near-Invariant betas. J Empir Financ 20(C):1-17

Asness CS, Moskowitz TJ, Pedersen LH (2013) Value and momentum everywhere. J Financ 68(3):929_ 985

Bai H, Hou K, Kung H, Li EX, Zhang L (2019) The CAPM strikes back? an equilibrium model with disasters. J Financ Econ 131(2):269-298

Berk JB, van Binsbergen JH (2016) Assessing asset pricing models using revealed preference. J Financ Econ 119(1):1-23

Black F (1972) Capital market equilibrium with restricted borrowing. J Bus 45(3):444-455

Black F, Jensen MC, Scholes M (1972) The Capital Asset Pricing Model: Some Empirical Tests. In: Jensen M. C. (ed) Studies in the Theory of Capital Markets. Praeger, New York, pp 79-121 
Blume M, Friend I (1970) Measurement of portfolio performance under uncertainty. Am Econ Rev 60(4):607-636

Blume M, Friend I (1973) A new look at the capital asset pricing model. J Financ 28(1):19-33

Bordo MD, Helbling T (2003) Have National Business Cycles Become More Synchronized?. NBER Working Paper No. 10130

Bruno V, Shin HS (2015) Cross-Border Banking and global liquidity. Rev Econ Stud 82(2):535-564

Burnside C, Eichenbaum M, Rebelo S (2004) Government guarantees and Self-Fulfilling speculative attacks. J Econ Theory 119(1):31-63

Buttiglione L, Lane PR, Reichlin L, Reinhart V (2014) Deleveraging? What Deleveraging?, Geneva Reports on the World Economy 16

Caballero R, Krishnamurthy A (2004) Smoothing sudden stops. J Econ Theory 119(1):104-127

Calderon C, Chong A, Stein E (2007) Trade Intensity and Business Cycle Synchronization: Are Developing Countries Any Different? J Int Econ 71(1):2-21

Calomiris CW, Mamaysky H (2019) How news and its context drive risk and returns around the world. J Financ Econ 133(2):299-336

Campbell JY (2018) Financial decisions and markets: a course in asset pricing. Princeton University Press, Princeton

Campbell JY, Vuolteenaho T (2004) Bad beta, good beta. Am Econ Rev 94(5):1249-1275

Chinn MD, Forbes KJ (2004) A decomposition of global linkages in financial markets over time. Rev Econ Stat 86(3):705-722

Chutasripanich N, Yetman J (2015) Foreign exchange intervention: Strategies and effectiveness BIS Working Paper No. 499

Cook D, Yetman J (2012) Expanding central bank balance sheets in emerging asia: a compendium of risks and some evidence. in are central bank balance sheets in asia too large?, 66, BIS Papers, pp 30-75

De Truchis G, Keddad B (2016) Long-Run Comovements in east asian stock market volatility. Open Econ Rev 27(5):969-986

Dées S, Zorell N (2012) Business cycle synchronisation: Disentangling trade and financial linkages. Open Econ Rev 23(4):623-643

Dumas B, Solnik B (1995) The world price of foreign exchange risk. J Financ 50(2):445-479

Fama EF, French KR (1992) The Cross-Section of expected stock returns. J Financ 47(2):427-465

Fama EF, French KR (1993) Common risk factors in the returns on stocks and bonds. J Financ Econ 33(1):3-56

Fama EF, French KR (1996) Multifactor explanations of asset pricing anomolies. J Financ 51(1):55-84

Fama EF, French KR (2004) The capital asset pricing model: Theory and evidence. J Econ Perspect 18(3):25-46

Fama EF, French KR (2006) The value premium and the CAPM. J Financ 61(5):2163-2185

Fama EF, French KR (2015) A Five-Factor asset pricing model. J Financ Econ 116(1):1-22

Fama EF, French KR (2016) Dissecting anomalies with a Five-Factor model. Rev Financ Stud 29(1):69103

Fama EF, MacBeth JD (1973) Risk, return, and equilibrium: Empirical tests. J Polit Econ 81(3):607-636

Frankel JA, Rose AK (1998) The endogeneity of the optimum currency area criteria. Economic Journal 108(449):1009-1025

Frazzini A, Pedersen LH (2014) Betting against beta. J Financ Econ 111(1):1-25

Frees EW (1995) Assessing Cross-Sectional Correlation in Panel Data. J Econ 69(2):393-414

Friedman M (1937) The Use of Ranks to Avoid the Assumption of Normality Implicit in the Analysis of Variance. J Amer Stat Assoc 32(200):675-701

Galstyan V, Velic A (2018) International investment patterns: The case of german sectors. Open Econ Rev 29(3):665-685

Gerlach-Kristen P, McCauley R, Ueda K (2016) Currency intervention and the global portfolio balance effect: Japanese lessons. J Jpn Int Econ 39(C):1-16

Grubel HG (1968) Internationally diversified portfolios: Welfare gains and capital flows. Am Econ Rev 58(5):1299-1314

Grubel HG, Fadner K (1971) The interdependence of international equity markets. J Financ 26(1):89-94

Harvey CR (1991) The world price of covariance risk. J Financ 46(1):111-157

Imbs JM (2004) Trade, finance, specialization, and synchronization. Rev Econ Stat 86(3):723-734

Imbs JM (2006) The real effects of financial integration. J Int Econ 68(2):296-324 
Jagannathan R, McGrattan ER (1995) The CAPM debate. Federal Reserve Bank of Minneapolis Quarterly Review 19(4):2-17

Jordà O, Schularick M, Taylor AM, Ward F (2018) Global financial cycles and risk premiums. CEPR Discussion Paper No. 12969

Kalemli-Ozcan S, Sorensen BE, Yosha O (2001) Economic integration, industrial specialization, and the asymmetry of macroeconomic fluctuations. J Int Econ 55(1):107-137

King M, Wadhwani S (1990) Transmission of volatility between stock markets. Rev Financ Stud 3(1):5-33

Korajczyk RA, Viallet CJ (1989) An empirical investigation of international asset pricing. Rev Financ Stud 2(4):553-585

Kose MA, Prasad ES, Terrones ME (2003) How Does Globalization Affect the Synchronization of Business Cycles? Amer Econ Rev 93(2):57-62

Lakonishok J, Shapiro AC (1986) Systematic risk, total risk and size as determinants of stock market returns. J Bank Financ 10(1):115-132

Lane PR, Milesi-Ferretti GM (2007) The external wealth of nations mark II: Revised and extended estimates of foreign assets and liabilities, 1970-2004. J Int Econ 73(2):223-250

Lee CH (1969) A Stock-Adjustment analysis of capital movements: The united States-Canadian case. J Polit Econ 77(4):512-523

Levy H, Sarnat M (1970) International diversification of investment portfolios. Am Econ Rev 60(4):668675

Lo AW (2017) Adaptive markets: Financial evolution at the speed of thought. Princeton University Press, Princeton

Miller NC, Whitman vNM (1970) A Mean-Variance Analysis of United States Long-Term Portfolio Foreign Investment. Q J Econ 84(2):175-196

Obstfeld M (2015) Trilemmas and Trade-Offs: Living with financial globalization. BIS Working Paper No. 480

Obstfeld M, Shambaugh JC, Taylor AM (2004) Monetary sovereignty, exchange rates, and capital controls: The trilemma in the interwar period. IMF Staff Pap 51(1):75-108

Obstfeld M, Shambaugh JC, Taylor AM (2005) The trilemma in history: Tradeoffs among exchange rates, monetary policies, and capital mobility. Rev Econ Stat 87(3):423-438

Pentecöte J-S, Poutineau J-C, Rondeau F (2015) Trade integration and business cycle synchronization in the EMU: The negative effect of new trade flows. Open Econ Rev 26(1):61-79

Pesaran MH (2004) General Diagnostic Tests for Cross Section Dependence in Panels. CESifo Working Paper No. 1229

Reinganum MR (1981) A new empirical perspective on the CAPM. J Financ Quant Anal 16(4):439-462

Rey H (2013) Dilemma not Trilemma: The Global Financial Cycle and Monetary Policy Independence. Proceedings, Economic Policy Symposium, Jackson Hole, Federal Reserve Bank of Kansas City, pp 285-333

Roll R, Ross SA (1994) On the Cross-Sectional relation between expected returns and betas. J Financ 49(1):101-121

Solnik BH (1974) The international pricing of risk: an empirical investigation of the world capital market structure. J Financ 29(2):365-378

Solnik BH (1977) Testing international asset pricing: Some pessimistic views. J Financ 32(2):503-512

Stambaugh RF (1982) On the exclusion of assets from tests of the Two-Parameter model: a sensitivity analysis. J Financ Econ 10(3):237-268

Publisher's Note Springer Nature remains neutral with regard to jurisdictional claims in published maps and institutional affiliations. 